\title{
Enhanced western mediterranean rainfall during past interglacials driven by North Atlantic pressure changes
}

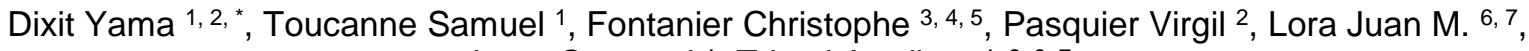 \\ Jouet Gwenael 1, Tripati Aradhna 1, 2, 6,7
}

\author{
1 IFREMER, Laboratoire Géophysique et enregistrement Sédimentaire, CS10070, 29280, Plouzané \\ cedex, France \\ 2 Université de Brest - UMR 6538 CNRS/UBO, LGO, IUEM, 29280, Plouzané, France \\ 3 Université de Bordeaux, CNRS, Environnements et Paléo-environnements Océaniques et \\ Continentaux, UMR 5805, F-33600, Pessac, France \\ ${ }^{4}$ FORAM, Research Group, F-49140, Villevêque, France \\ 5 Université d'Angers, F49035, Angers, France \\ ${ }^{6}$ Department of Atmospheric and Oceanic Sciences, Institute of the Environment and Sustainability, \\ Center for Diverse Leadership in Science, University of California, Los Angeles, USA \\ 7 Department of Earth, Planetary, and Space Sciences, Center for Diverse Leadership in Science, \\ University of California, Los Angeles, USA
}

* Corresponding author : Yama Dixit, email address : ydixit@ntu.edu.sg

\begin{abstract}
:
There is increasing concern with anthropogenic greenhouse gas emissions that ocean warming, in concert with summer and winter precipitation changes, will induce anoxia in multiple ocean basins, such as in the Mediterranean Sea. Although the hydrological changes in the eastern Mediterranean are quite well constrained, quantitative evidence of changes in sea surface temperature (SST) and winter rainfall in the western Mediterranean across the past interglacials is relatively scarce. In this study, we use a combination of trace element $(\mathrm{Ba} / \mathrm{Ca}$ and $\mathrm{Mg} / \mathrm{Ca}$ ) and stable oxygen isotope composition of planktonic foraminifera from a sediment core located off the Golo River, Corsica (northern Tyrrhenian Sea) to reconstruct variations in SSTs and sea surface salinities (SSS) during the Holocene (MIS 1) and warm periods of the past two interglacials (MIS 5, 7). We also analyse PMIP3 model simulations for the midHolocene to investigate the mechanism for moisture transport in the western Mediterranean. Our Mg/CaSSTs, Ba/Ca-salinity and derived $\delta 180$-seawater records suggest that the warm periods of the Last interglacials were characterized by high river discharge and lower SSS in the northern Tyrrhenian Sea. Since this region is ideally located on the trajectory of wintertime storm tracks across the North Atlantic into the Mediterranean Sea and is also outside the influence of the ITCZ-controlled summer monsoon rains, we suggest enhanced winter rainfall during the past interglacials. Our analysis of PMIP3 model simulations for mid-Holocene also support increased south-westerly moisture transport into the western Mediterranean originating from the North Atlantic. We also find evidence that long-term amplitude of the salinity decrease tightly follows eccentricity. We suggest that these hydrologic changes in the western Mediterranean, and the northern Mediterranean borderlands as a whole, were a contributing factor, together with local cyclogenesis and African summer monsoon rainfall, to basin-wide anoxia in the past. Our findings offer new constraints to the amplitude and cause of winter rainfall changes in the Mediterranean during past warm periods.
\end{abstract}


Keywords : Western mediterranean, Interglacials, Mg/ca-SST, Ba/ca-salinity, Sapropel, Foraminifera 


\section{Introduction}

45 The hydrology and ecosystems of the Mediterranean are highly vulnerable to the impacts of climate change (Guiot and Cramer, 2016; IPCC AR4, 2014). Indeed, it is well-known that in the past periods of disruption in Mediterranean hydrological cycle led to development of anoxia leading to sapropel deposition (Rohling et al., 2015 and references therein). Owing to its location, the Mediterranean Sea is sensitive to oceanic and atmospheric circulation changes originating both from the low and high

50 latitudes i.e. latitudinal migration of the Inter-Tropical Convergence Zone (ITCZ) and the Atlantic processes that drives the wintertime Mediterranean storm track respectively. Past hydrological changes in the eastern Mediterranean Sea, as today, were primarily controlled by the variability in the summer monsoon rainfall due to the movement of the ITCZ communicated into the Mediterranean basin via North African paleo-river runoff (Rossignol-Strick, 1983; Rossignol-Strick et al., 1985; Rohling et al.,

55 2002; Revel et al., 2010). In the western Mediterranean basin and northern borderlands, the modern hydrological changes are more dependent on the North Atlantic atmospheric circulation that brings about winter rains (Trigo et al., 2002; Kandiano et al., 2014).

Since Mediterranean region receives highest precipitation amounts annually during winters (October to March), changes in winter rainfall are critical for socioeconomic development of the region. However,

60 past precipitation changes during the winter months in the western Mediterranean are less constrained and there still remains a lot of ambiguity on the pattern and mechanism of winter rainfall variability, specifically on Quaternary timescales (IPCC, 2014). Although a wealth of proxy data and numerical simulations exist for the eastern Mediterranean (see Rohling et al., 2015 for a detailed review), the evidence for rainfall variability in the western Mediterranean covers only the Holocene (Carrión, 2002;

65 Zanchetta et al., 2007; Fletcher and Sánchez Goñi, 2008; Magny et al., 2011; 2013; Peyron et al., 2011; Zielhofer et al., 2017), Marine Isotope Stage (MIS) 5e i.e. the warm period of the Last interglacial (Drysdale et al., 2005; Milner et al., 2012; Regattieri et al., 2014) and period covering MIS 3- 6 (Kallel et al., 2000; Bard et al., 2002). In this light, direct rainfall/sea surface salinity (SSS) and sea surface temperature (SST) estimates from well-located, regionally representative archives that cover multiple 
70 interglacial periods, is key to addressing long-standing questions regarding the amplitude of winter $\mathrm{p}$ Joumal Pre-proof

In this study, we bridge the data gap from the western Mediterranean by investigating SSS and SST changes using marine sediment core GDEC-4-2 located off eastern Corsica (Fig. 1). Previously, Toucanne et al. (2015) used indirect sedimentological proxies from GDEC-4-2 to propose enhanced

75 North Atlantic-sourced rainfall in the western Mediterranean during warm intervals of interglacial periods over the last $547 \mathrm{ka} \mathrm{BP}$. Here, we build-up on the existing work by Toucanne et al. (2015) and develop an independent direct geochemical record (trace element and stable isotopes of the planktonic foraminifera Globigerina bulloides) to assess precipitation variability by reconstructing runoff (rainfall/salinity) and temperature changes at the GDEC-4-2 site during the Holocene (MIS 1), the last

80 (MIS 5) and penultimate (MIS 7) interglacials (Fig. 1).

\section{Materials and Methods}

\subsection{Sediment core GDEC4-2}

Core GDEC-4-2 $\left(042^{\circ} 31.23 .2^{\prime} \mathrm{N}, 09^{\circ} 42.59 .5^{\prime} \mathrm{E}, 492 \mathrm{~m}\right.$ water depth) was recovered from the upper continental slope near the mouth of the Golo river, eastern Corsica (Fig. 1; see Toucanne et al., 2015 for

85 details). Corsica is considered to be a highly sensitive paleoclimatic key area within the Mediterranean (Kuhlemann et al., 2008). The Golo is a short, mountainous river (maximum altitude of ca. $2700 \mathrm{~m}$ ) and was the most important source of Pleistocene-Holocene terrigenous sediment to the adjacent margin (Calves et al., 2013; Sweet et al., 2019). The Golo river system is a typical example of a 'reactive' sediment routing system (sensu Allen, 2008), as it responds simultaneously to climate-driven changes

90 and is therefore well-suited for studying the 'source to sink' dynamics and past changes in hydrology (Calves et al., 2013; Toucanne et al., 2015). The studied interval is composed of hemipelagic sediments, mainly silty-clay carbonate rich intervals.

The hydrography at GDEC-4-2 site is mainly influenced by the Levantine Intermediate Water (LIW) circulation (from ca. 200 to 600-1000 m water depth) (Fig.1) (see Toucanne et al., 2012 for detail

95 information on hydrography of this region). The LIW is formed in the Levantine Basin (eastern 
Mediterranean) in a permanent large-scale cyclonic Rhodes gyre through summer evaporation and W

al., 1992). It forms the major water mass flowing from the east to west, along with the Aegean and Adriatic water contributions. In the northern Tyrrhenian Sea, a portion of the LIW flows northwards

100 through the Corsica Trough, while the other part flows southwards to the Sardinia Channel, then along the western slope of Sardinia and Corsica before its intrusion into Ligurian Sea. The LIW contributes to the Western Mediterranean Deep Water production after reaching the Gulf of Lion and both water masses contribute to ca. $80 \%$ and $20 \%$ to the Mediterranean Outflow water (MOW), respectively (Pinardi and Masetti, 2000).

\section{$105 \quad 2.2$ Stable isotope analyses}

The planktonic foraminifera G. bulloides, that occurs virtually continuously throughout the interglacial intervals of core GDEC-4-2, was selected for the stable oxygen and carbon isotope analysis using 15-20 specimens from the 250-300 $\mu \mathrm{m}$ size fraction. We use previously published stable isotopic results from Toucanne et al. (2015) for the Holocene and MIS 7c and 7e periods. For MIS 5e period, we sampled G.

110 bulloides for isotopic analysis as G.bulloides isotopic data for this interval is not used in Toucanne et al. (2015) (Fig. 2a). The temporal resolution for stable isotope data ranges from $\sim 0.2-3 \mathrm{ka} \mathrm{BP} / \mathrm{per}$ measurement. Oxygen isotope ratios for MIS 5e were measured using Thermo Scientific Delta V plus Isotope Ratio Mass Spectrometer fitted with a GasBench II preparation and introduction device, operated by Pôle Spectrométrie Océan (PSO, IFREMER, IUEM, CNRS), located at the Institut

115 Universitaire Européen de la Mer (IUEM / UBO) at Plouzané, France (For details on the analytical methods for other interglacials, please refer to Toucanne et al., 2015). The stable isotopes are expressed as $\delta^{18} \mathrm{O}$ relative to the Vienna Pee Dee Belemnite (V-PDB) standard. VPDB is defined with respect to the NBS-19 calcite standard $\left(\delta^{18} \mathrm{O}=-2.20 \%\right.$ ). The mean external reproducibility $(1 \sigma)$ determined from replicate measurements of powdered internal carbonate standards is $0.02 \%$ for $\delta^{18} \mathrm{O}$. 
$\mathrm{T}$ Journal Pre-proo

the 250-300 $\mu \mathrm{m}$ fraction for each analysis. The temporal resolution for trace element record ranges from $\sim 0.2-2$ ka BP/per analysis (Fig. 2b). G. bulloides occurred continuously throughout the sediment core, as compared to other planktonic foraminifera such as Globigerinoides ruber and Neogloboquadrina

125 pachyderma, and therefore was used to obtain a continuous isotopic and trace element record. Under modern conditions, G. bulloides develops preferentially during the late winter/ spring bloom in the Mediterranean Sea (Pujol and Grazzini, 1995). Our reconstructed Mg/Ca-SSTs of the western Mediterranean Sea therefore reflect late winter/spring temperatures. G. bulloides calcifies in the upper $60 \mathrm{~m}$ of the water column and it is assumed that proxy data obtained from it are representative of a 130 mean calcification depth of $30 \mathrm{~m}$ and reflect surface water conditions (Barker and Elderfield, 2002). We measured trace element ratios on a ThermoFinnigan Element2 sector field inductively-coupled plasma mass spectrometer (HR-ICP-MS) following the analytical methods detailed by Marchitto, 2006). To check for internal inconsistencies, recurrent analysis of an internal consistency standard solution analysed over the course of entire study provides analytical precision of $\pm 2.6 \%$ (1бRSD) for $\mathrm{Ba} / \mathrm{Ca}$ and

$1350.7 \%$ for $\mathrm{Mg} / \mathrm{Ca}$ based on 121 analysis. Reproducibility based on replicate measurements of foraminiferal samples in this study is $5.4 \%$ (mean RSD) for $\mathrm{Ba} / \mathrm{Ca}$ and $0.05 \%$ for $\mathrm{Mg} / \mathrm{Ca}$. Accurate determination of magnesium and barium can be biased by preferential dissolution, and/or by the presence of contaminant phases that are mostly attached or adsorbed onto foraminiferal shell tests, such as Fe-Mn oxyhydroxides, Mn-rich carbonate overgrowths (as a consequence of high

140 alkalinity/salinity environments), clay minerals and organic detritus (Boyle, 1983; Lea and Boyle, 1991; Barker et al., 2003; Pena et al., 2005; Ferguson et al., 2008; Hoogakker et al., 2009; Boussetta et al., 2011; van Raden et al., 2011; Cisneros et al., 2016). Although the location of GDEC-4-2 in the western Mediterranean has lower salinity/alkalinity waters as compared to sites in the eastern Mediterranean (Antonov et al., 2006), the impact of strong salinity changes in the Mediterranean Sea (Ferguson et al.,

145 2008) that can promote secondary carbonate overgrowths was examined by using various chemical cleaning procedures on two sets of samples from the same depths (Fig. S1, S2). This is a common procedure routinely used to test the efficacy of cleaning methods (Ezat et al., 2016; Weldeab et al., 
2006). The two sets of samples were chemically cleaned following the oxidative and reductive-

O

150 phases and were then compared to examine evidence for any overgrowths that occur in high salinity waters (Hoogakker et al., 2009). This comparison (Fig. S1-S2) shows there is no discernable difference between cleaning methods on these samples, and that SSTs are similar to what would be expected for the region based on other studies (Ferguson et al., 2008; Cisneros et al., 2016; Ezat et al., 2016). Thus it is unlikely that Mn-Mg-rich overgrowths in GDEC-4-2 foraminifera shells, generally observed in the

155 eastern Mediterranean due to high salinities (Hoogakker et al., 2009) is impacting samples from this region of the Western Mediterranean.

The efficiency of the removal of contaminant phases by chemical cleaning was also assessed through the determination of $\mathrm{Fe} / \mathrm{Ca}, \mathrm{Al} / \mathrm{Ca}$ and $\mathrm{Mn} / \mathrm{Ca}$ ratios of the samples. An influence of $\mathrm{Fe}-\mathrm{Mn}$ oxyhydroxides on $\mathrm{Ba} / \mathrm{Ca}$ ratios is reflected in a co-variation of $\mathrm{Fe} / \mathrm{Ca}$ and $\mathrm{Mn} / \mathrm{Ca}$ ratios with $\mathrm{Ba} / \mathrm{Ca}$

160 values. Non-removed clay detritus generally leads to high $\mathrm{Al} / \mathrm{Ca}$ ratios in the samples. High $\mathrm{Mn} / \mathrm{Ca}$ ratios may indicate the presence of manganese-rich carbonate overgrowths (Boyle, 1983; Hoogakker et al., 2009). In sediment core GDEC-4-2, $\mathrm{Ba} / \mathrm{Ca}$ and $\mathrm{Mg} / \mathrm{Ca}$ values show no relationship $\left(\mathrm{r}^{2}<0.1\right)$ with $\mathrm{Al} / \mathrm{Ca}, \mathrm{Mn} / \mathrm{Ca}$ and $\mathrm{Fe} / \mathrm{Ca}$ (Fig. S2). This implies that iron-manganese oxides and clay minerals are not biasing the resultant $\mathrm{Mg} / \mathrm{Ca}$ and $\mathrm{Ba} / \mathrm{Ca}$ record. The range of $\mathrm{Ba} / \mathrm{Ca}$ in $\mathrm{G}$. bulloides is generally higher 165 than other species (for example, Weldeab et al., 2007; Ferguson et al., 2008) but is comparable to that observed in previous studies on G. bulloides from Mediterranean and other regions (Ferguson et al., 2008; Sprovieri et al., 2008; Marr et al., 2013). Lea and Boyle, (1991) suggested that several planktonic foraminifera species have high $\mathrm{Ba} / \mathrm{Ca}$ ratios owing to the differences in the way these foraminifera precipitate their shells.

170 We used McConnell and Thunell, (2005) calibration for SST determination from G. bulloides $\mathrm{Mg} / \mathrm{Ca}$ measurements, which overlap with our samples such that the absolute values are applicable for temperatures up to $33^{\circ} \mathrm{C}$ (Fig. S1, S2, S3). Because of the absence of coastal upwelling, SST estimates generally reflect regional atmospheric temperatures, except during times of high riverine input when water temperatures can be decoupled from local atmospheric conditions (Fig. S4). We also develop two

175 independent records to constrain river runoff at our site: the oxygen isotope ratio of local seawater 
$\left(\delta^{18} \mathrm{O}_{\mathrm{sw}}\right)$ and the $\mathrm{Ba} / \mathrm{Ca}$ ratio of planktonic foraminifera. Both methods have different sources of $\mathrm{u}$ Journal Pre-proot

precipitation and riverine runoff are reflected in the $\delta^{18} \mathrm{O}_{\mathrm{sw}}$ and budget of dissolved Ba at GDEC-4-2, which are, in turn, archived in foraminifera tests that accumulate in marine sediments.

\subsection{Chronology}

We followed the chronology described in Toucanne et al. (2015), which is constrained by aligning the planktonic $\delta^{18} \mathrm{O}$, weight percent $\mathrm{CaCO}_{3}$ and XRF-Ca/Ti to the NGRIP ice core $\delta^{18} \mathrm{O}$ record from Greenland for the last 60 ka GICC05 chronology; Rasmussen et al., 2006; Svensson et al., 2008) and to the synthetic Greenland (GLTsyn) record of Barker et al. (2011) from 60 to 550 ka BP. For T-II and

185 MIS 5, we synchronized $\delta^{18} \mathrm{O}$ of $G$. bulloides to the most up-to-date radiometrically-constrained chronology of ODP Site 975 (Marino et al., 2015) (See Table S1 for control tie-points used for tuning our record). Marino et al. (2015) obtained a new radiometrically constrained chronology for ODP975 across T-II and the Last interglacial period exploiting the well-documented intermediate-water connectivity between the eastern and western Mediterranean Sea, and the relationship between marine surface water microfossil $\delta^{18} \mathrm{O}$ and U-series-dated regional $\delta^{18} \mathrm{O}$ speleothem records. This was done to obtain a regionally (both eastern and western Mediterranean) synchronous picture for this time period. The $\delta^{18} \mathrm{O}$ of planktonic foraminifera G. bulloides from the site ODP 975 is synchronized to the Soreq Cave speleothem and $\delta^{18} \mathrm{O}$ of G. bulloides from marine core LC21 in the eastern Mediterranean, and to $\delta^{18} \mathrm{O}$ of G. bulloides of ODP Sites 976, 977 and core MD01-2444 in the western Mediterranean, thereby 195 to the SST and/or IRD records of North Atlantic climate variability that are archived in the Iberian margin sediment cores (see supplementary information, Table S1).

\subsection{Proxy systematics}

The $\delta^{18} \mathrm{O}$ in foraminiferal calcite is controlled by calcification temperature and by the $\delta^{18} \mathrm{O}_{\mathrm{sw}}$ (Bemis et al., 1998). $\delta^{18} \mathrm{O}_{\mathrm{sw}}$ was estimated using $\mathrm{Mg} / \mathrm{Ca}$-based-SST in concert with analysed calcite $\delta^{18} \mathrm{O}$ $200\left(\delta^{18}\right.$ Ocalcite) for $G$. bulloides $\left(\delta^{18} \mathrm{O}_{\text {G. bulloides }}\right)$ and temperature - $\left(\delta^{18}\right.$ Ocalcite $\left.-\delta^{18} \mathrm{O}_{\text {sw }}\right)$ relationship (Bemis et al., 1998). $\delta^{18} \mathrm{O}_{\mathrm{sw}}$ in turn is controlled by freshwater variations due to river runoff, and 
changes in the isotopic composition of river water and seawater. The latter in turn reflects changes in $\mathrm{p}$

changes.

205 Foraminiferal $\mathrm{Ba} / \mathrm{Ca}$ is used as an independent proxy for riverine runoff and rainfall changes (Weldeab et al., 2007) (Fig. S5). Seawater $\mathrm{Ba}\left(\mathrm{Ba}_{\mathrm{sw}}\right)$ concentrations at sites influenced by riverine discharge are highly correlated to salinity because dissolved $\mathrm{Ba}$ is high in riverine water and $\mathrm{Ba}$ desorbs from suspended sediments in estuaries (Coffey et al., 1997). Ba incorporation in foraminiferal calcite varies linearly with changes in $\mathrm{Ba}_{\mathrm{sw}}$ and is therefore independent of temperature and alkalinity (Hönisch et al.,

210 2011). We also attempted to use the modern $\mathrm{Ba} / \mathrm{Ca}_{\mathrm{sw}}$-salinity relationship obtained off the Golo River to obtain a first-order estimate of the past runoff-induced SSS variations, as recorded by $\mathrm{Ba} / \mathrm{Ca} \mathrm{a}_{\text {foram }}$.

\subsection{PMIP3 model simulations}

In order to simulate the changes in intensity of North Atlantic sourced rainfall in the western Mediterranean, we analysed mid-Holocene and pre-industrial (PI) simulations from 12 models that

215 participated in the Paleoclimate Modelling Intercomparison Project Phase 3 (PMIP3) (Braconnot et al., 2012), and which are tabulated in Table S1. We only used the latest generation of PMIP experiments (PMIP3; Braconnot et al., 2011; Harrison et al., 2015), which are now a part of the Coupled Model Intercomparison Project phase5 (CMIP5, Taylor et al., 2011). The PMIP3 mid-Holocene (6 ka) experiment consists of equilibrium simulations run with modified orbital parameters and greenhouse 220 gas concentrations. Mid-Holocene conditions differ from the PI period through their orbital configuration and reduced atmospheric greenhouse gas concentrations $\left(\mathrm{CH}_{4}\right.$ reduced to $\left.650 \mathrm{ppb}\right)$. The orbital configuration modifies the seasonal distribution of heat between the Northern and Southern hemispheres with an increase (reduction) of thermal seasonality in the Northern (Southern) hemisphere. Aerosols, solar constant, vegetation, ice sheets, topography, and coastlines are prescribed as the same as 225 the PI experiment. 


\section{Results}

3

foumal Pre-proo

The GDEC-4-2 $\delta^{18} \mathrm{O}_{\text {G. bulloides }}$ record shows higher values during glacial periods. The $\delta^{18} \mathrm{O}_{\text {G. bulloides }}$

230 progressively decrease across Heinrich Stadial (HS) 1 at $\sim 18-15$ ka BP (Fig. 2a) and HS-11 at $~ 135-130$ ka BP (Fig. 2a), and these intervals are also characterized by colder Mg/Ca-based-SSTs averaging 14 $\pm 0.12^{\circ} \mathrm{C}$ and $\sim 13 \pm 0.13^{\circ} \mathrm{C}$, respectively (Fig. 2b). The timing of abrupt cooling recorded at our site is consistent with colder SSTs reported for nearby ODP Site 976 (Martrat et al., 2014) in the western Mediterranean Sea (Fig. 3a, 3b). The $\delta^{18} \mathrm{O}_{\mathrm{sw}}$ record (uncorrected by ice-volume changes) also shows 235 concomitant decreasing values, with the largest change $(\sim 2.5 \pm 0.3 \%$ o $)$ during $\mathrm{HS}-11$, while $\mathrm{Ba} / \mathrm{Ca}$ shows no significant change during these periods, suggesting a dominant influence of North Atlantic hydrographic changes, during the Heinrich Stadials, in the western Mediterranean and relatively negligible local hydrological changes (inferred from Ba/Ca values) (Fig. 3c). Similarity in magnitude of change in the $\delta^{18} \mathrm{O}_{\text {G. bulloides }}$ at GDEC-4-2 and that observed at site ODP-975 (Marino et al., 2015) (Fig.

240 3a) indicate that the HS-11 freshwater inputs from deglacial iceberg melting entered the Mediterranean Sea via the Strait of Gibraltar impacted ODP 975 and had imprints as far as the GDEC-4-2 site (Rodríguez-Sanz et al., 2017).

The $\delta^{18} \mathrm{O}_{\text {G. bulloides }}$ and calculated $\delta^{18} \mathrm{O}_{\mathrm{sw}}$ records are characterized by depleted values marking the glacial terminations T-I centred at $\sim 10 \mathrm{ka} \mathrm{BP}, \mathrm{T}-\mathrm{II}$ at $\sim 127.5 \mathrm{ka} \mathrm{BP}$ and T-III at $\sim 241 \mathrm{ka} \mathrm{BP}$ (Barker et al., 245 2019) and by lowest values during the early-mid Holocene MIS 1 (10-6 ka BP), MIS 5e (129-125 ka BP), MIS 7c (220-209 ka BP) and MIS 7e (242-237 ka BP) (Lisiecki and Raymo, 2005), respectively (Fig. 2a, 4a). These globally warm periods are characterized by increased Mg/Ca-based-SSTs at GDEC4-2 with $\sim 18^{\circ} \mathrm{C}$ Holocene values, and MIS 5e being the warmest with temperatures averaging $\sim 24^{\circ} \mathrm{C}$, although at this site, our SST reconstructions indicate increased riverine discharge during MIS 7c and 2507 7e that led to local SST being cooler (Fig. S4, 4b).

\subsection{Precipitation and salinity changes inferred from foraminifera $\mathrm{Ba} / \mathrm{Ca}$}

At GDEC-4-2, high Ba/Ca values characterized the warm periods MIS 1, MIS 5e, MIS 7c and MIS 7e, respectively. $\mathrm{Ba} / \mathrm{Ca}$ values are highest during MIS-7c and 7e, which coincided with increased 
abundance of benthic foraminiferal assemblages (Toucanne et al., 2015) suggesting increased import of 255

effects on the primary productivity and the marine organic matter flux to the seafloor, conducive to the development of high benthic foraminifera populations (Rohling and Hilgen, 1991). The unique location of core GDEC-4-2 on the upper continental slope at Golo river mouth limits the Ba concentration in the water column and at the sediment-water interface and contribution of barite in Ba measurement as

260 previously reported in other western Mediterranean site (Martínez-Ruiz et al., 2003). High Ba/Ca ratios are also accompanied by a corresponding drop in $\delta^{18} \mathrm{O}_{\mathrm{sw}}$ during each of the warm interglacial periods, MIS 1, MIS 5e and MIS 7c and 7e respectively (Fig. 4c,d).

\section{Discussion}

\subsection{Mediterranean hydroclimate changes during the last three interglacials}

265 Our geochemical data show that SST in the western Mediterranean during the Last interglacial (MIS 5e) were consistently higher than late-Holocene temperatures which corroborates with SST estimates from the nearby ODP Site 976 in the western Mediterranean (Martrat et al., 2014; Fig. 4b). For MIS7, the observed difference in reconstructed SSTs between ODP Site 976 and GDEC-4-2 stems from increased riverine discharge bathing GDEC-4-2 site with cooler waters during MIS 7c and 7e (Fig. S4).

270 Lower $\delta^{18} \mathrm{O}_{\text {G.bulloides }}$ values observed in the western Mediterranean Sea sites GDEC-4-2 and ODP 975 (Marino et al., 2015) during the Holocene and the Last interglacial, reflect the combined changes in global sea level/ice volume, regional evaporation/precipitation and also the warming of surface waters from which the foraminifera calcified in. Close correspondence of $\delta^{18} \mathrm{O}_{\text {G.bulloides }}$ values at sites GDEC-42 and ODP 975 (Fig. 3a) and with Tana Che Urla Cave from the Italian peninsula (Fig. 3e) also

275 demonstrate the regional characteristics of the western Mediterranean seawater and attests the fidelity of the newly acquired high-resolution $\delta^{18} \mathrm{O}_{\text {G.bulloides }}$ data for MIS 5e, building upon the existing Toucanne et

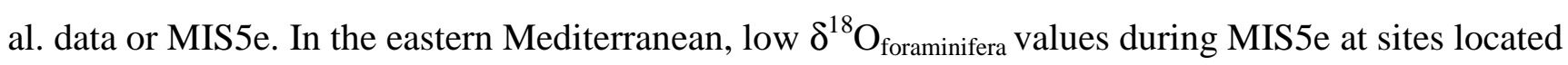
in the Aegean Sea (Fig. 3f) has been previously attributed to intensified North African Monsoon (as Northern Hemisphere insolation peaked and the ITCZ moved northward) that delivered large amounts 
280 of freshwater into the eastern Mediterranean via the Nile and other North African rivers around 1281 Journal Pre-proof

evaporation/precipitation signal from the global ice-volume and ensuing sea level changes, limits the use of $\delta^{18} \mathrm{O}_{\mathrm{sw}}$ to examine local hydrological changes. Therefore, at GDEC-4-2 site, the $\delta^{18} \mathrm{O}_{\mathrm{sw}}$ reflect a combined signature of global ice-volume changes and changes in regional evaporation/precipitation and 285 the $\mathrm{Ba} / \mathrm{Ca}$ record for river discharge provided independent estimates of the change in SSS for the past interglacials, with high Golo runoff implying increased local precipitation during warm intervals in the western Mediterranean. To estimate past SSS, we also collected seawater samples from the Golo river mouth to the open sea and simultaneously recording the salinity at each sample collection site. Accurate estimation of SSS, however, could not be obtained owing to limited number of paired seawater samples

290 and salinity measurements along the river out to the open sea (four distinct paired measurements; Fig. S5), nevertheless we have estimated SSS using the available data to get a broad idea of the SSS changes in the past (Fig. 4d).

The GDEC-4-2 site is ideally located on the way of North Atlantic depression into the Western Mediterranean Sea (Hoskins and Hodges, 2002; Bengtsson et al., 2009; Kutzbach et al., 2014), such that 295 the composition of the sediment core faithfully captures the variation in winter storm tracks in the sediments (Toucanne et al., 2015). High foraminifera Ba/Ca ratios (low salinities) recorded at GDEC4-2 during MIS1, MIS5e, MIS7e and 7c therefore indicate increased runoff/rainfall during winter periods. Although speleothems around the Mediterranean Sea are suggested to have a strong source water effect during glacial to interglacial transitions (Rohling et al., 2015), periods of increased rainfall inferred

300 from high $\mathrm{Ba} / \mathrm{Ca}$ and lower SSS at GDEC-4-2 during MIS 5e, correlate well with wetter conditions in Italy, inferred from lower $\delta^{18} \mathrm{O}_{\text {calcite }}$ values in speleothems from both Corchia and Tana Urla caves and lake carbonates of the Sulmona Basin (Drysdale et al., 2005; Regattieri et al., 2014; Tzedakis et al., 2018) (Fig. 3). Recently, Pasquier et al. (2019) reported episodes of enhanced proportion of landderived material suggesting significant increase in wintertime precipitation amount over the Gulf of

305 Lion catchment area during the warm intervals of both Holocene and MIS 5, further attesting the regional winter precipitation pattern in the western Mediterranean and its northern borderlands. Similarly, palynological evidence from Tenaghi Philippon (Greece) reveal the expansion of 
Mediterranean sclerophyllous vegetation and temperate tree pollen, indicative of summer aridity and e

310 3). Our site GDEC4-2 and other discussed western and northern Mediterranean sites (Corchia Cave, Tana Urla Cave, Gulf of Lion marine sediment core) (Fig. 1) reveal that these archives record enhanced winter rainfall during the Holocene and the Last interglacial. Interestingly, our geochemical records also show that increased wintertime precipitation and lower SSS in the western Mediterranean extended as far back as the warm intervals of penultimate interglacial, MIS 7c and 7e, corroborating with previous

315 sedimentological work at GDEC-4-2 (Toucanne et al., 2015) and recent multi-proxy records from Lake Ohrid (Wagner et al., 2019) (Fig. 4c-e). These results therefore support the hypothesis that high rainfall during interglacials was a distinctive feature of Mediterranean hydroclimate (Sierro et al., 2000; Valero et al., 2014), confirming by extension that the precession minima (boreal summer insolation maxima and winter minima) paced rainfall variability.

320 The most striking feature in our geochemical record is that the change in amplitude of $\mathrm{Ba} / \mathrm{Ca}$ (and $\mathrm{Ba} / \mathrm{Ca}$-derived SSS, Fig. 4d) follows the eccentricity cycle closely, such that higher $\mathrm{Ba} / \mathrm{Ca}$ (and lower SSS) during MIS 7, relatively lower Ba/Ca (and higher SSS) in MIS 5, and the lowest $\mathrm{Ba} / \mathrm{Ca}$ (and highest SSS) in MIS 1, correspond to the respective insolation maxima of the 100 ka-eccentricity cycle during each interglacial (Fig. 5). This trend, which reflect the changes in magnitude of river discharge in 325 response to winter rainfall, likely suggest that the precession-paced rain was tightly linked with eccentricity changes. This could highlight an eccentricity modulation of the precession-driven rainfall/runoff in the western Mediterranean during the late Pleistocene. This is also in line with previous work from southern Spain for the Pliocene period (Sierro et al., 2000) and more recently also documented in Lake Ohrid (Wagner et al., 2019). Previously enhanced North African summer monsoon

330 and Mediterranean precipitation during increased insolation seasonality were linked to minimum precession, high eccentricity and maximum obliquity (Bosmans et al., 2015a, 2015b; Kutzbach et al., 2014; and references therein). A role of obliquilty forcing along with precession forcing, in increasing the seasonality and influencing Mediterranean winter rainfall, has also been proposed (Bosmans et al., 2015a). Analysis of ocean-atmosphere-vegetation simulations through an entire late Miocene precession 335 cycle also suggest influence of precession on the cyclic sedimentary patterns in the marine record of the 
Mediterranean Sea (Marzocchi et al., 2019). Our geochemical evidence from western Mediterranean

cl

Journal Pre-proot

precessional changes which in turn are modulated by eccentricity.

\subsection{Proposed mechanism for high Mediterranean winter precipitation during the mid-Holocene}

We analysed climate model simulations from the Paleoclimate Model Intercomparison Project Phase 3 (PMIP3); Braconnot et al., 2011) to shed light on the variability of winter precipitation during the Holocene and also to examine the source of the wintertime Mediterranean rainfall, with the caveat that we are limited by the lack of model output for earlier interglacials. Indeed the direct comparison is most relevant for the Holocene, where we have proxy data and model simulations, whereas older

345 interglacials would be more accurately represented by different boundary conditions.

Our model analysis for the mid-Holocene at $\sim 6 \mathrm{ka}$ (as used in PMIP3) compared to preindustrial (PI) conditions) suggests enhanced southwesterly mean moisture transport from the North Atlantic causing higher moisture convergence during winters in the Mediterranean, potentially brought about by a south-eastward shift of storm tracks (Fig. 6a) during the mid-Holocene, in a negative North

350 Atlantic Oscillation (NAO)-type pattern. All the mid-Holocene model outputs from our model analysis are in good agreement with the mid-Holocene high lake levels, which indicate increased precipitation minus evaporation $(\mathrm{P}-\mathrm{E})$ due to increased winter precipitation during the early-mid Holocene (10-6 ka BP) on the western and northern Mediterranean borderlands (Magny et al., 2012) (Fig. 6b). Interestingly, the east-west and north-south gradient in precipitation pattern noted by previous studies

355 (Dormoy et al., 2009; Magny et al., 2013) is consistent with the increased south-westerly transport in the region, such that the records showing wetter mid-Holocene lie in the stippled area of our simulation results indicating increased moisture. A similar pattern of wetter winter with a strong seasonal cycle of surface air temperatures during the mid-Holocene was also observed in previous general circulation model simulations (Brayshaw et al., 2011). In particular, a stronger southwesterly flow during the

360 winter 6kaBP experiment (compared with the PI control run) was clearly shown such that the northern coast and western Mediterranean received strong precipitation (Brayshaw et al., 2011). Comparison of Holocene proxy-models using regional scale downscaling of a set of global climate model simulations 
for the Mediterranean region also give consistent results (Peyron et al., 2017). Our Ba/Ca- river $\mathrm{rl}$

365 confidence to previous findings on the mechanistic understanding of the Mediterranean winter rains during the Holocene.

Recent extreme rainfall events over the northern Mediterranean borderlands have a distinct North Atlantic origin of moisture (Celle-Jeanton et al., 2001). Today, NAO is the dominant atmospheric phenomena in the North Atlantic and Mediterranean region during winters (Hurrell, 1995; Trigo et al.,

370 2002; Olsen et al., 2012) (Fig. 1), such that during the negative phase of NAO, storm tracks are shifted southwards that bring wet and mild winters over the southern Europe. Fluctuations in NAO strongly affects the intensity of zonal flows over the North Atlantic (i.e. westerlies), the position of storm tracks and subsequent precipitation amount across Europe and the Mediterranean basin (López-Moreno et al., 2011). Coupled atmosphere-ocean general circulation model suggest that such NAO-type mode of 375 climate variability could also have operated at orbital timescales such as MIS 5e (Lohmann, 2017). Wagner et al., (2019) compared annual cycle of simulated Lake Ohrid precipitation data with modern reanalysis data to show that current drivers of the amount of rainfall in the Mediterranean share similarities to those that drove the reconstructed increases in precipitation in the past i.e. a North Atlantic control on the Mediterranean winter precipitation. A North Atlantic connection of winter

380 rainfall during the past interglacials on the Northern Mediterranean borderland was also suggested using palynological proxies from the Iberian margin (Amore et al., 2012) and more recently using geochemical proxies from the Gulf of Lion (Pasquier et al., 2019). Lipid isotopic records from Tenaghi Philippon (Greece) for the MIS 10-11 period also document North Atlantic moisture signal in winter precipitation (Ardenghi et al., 2019). Moreover, geochemical and mineralogical evidence from marine 385 records in the central Mediterranean suggest that the North-African paleo-river systems were reactivated by enhanced summer monsoon precipitation, when the ITCZ penetrated sufficiently northward after the last deglaciation (Wu et al., 2017). The variability of such paleo-river inputs are suggested to follow the Western African monsoon rainfall, which in turn is controlled by the Atlantic Ocean climate. Similarities in the timing of increased runoff/rainfall during S1 observed in GDEC-4-2 and that in the records of North-African paleo-rivers (e.g. Wu et al., 2017), lend further support to the 
point that the Atlantic plays a key role in the correspondence between summer monsoon and winter rs

We emphasize this model-data comparison is limited because previous coordinated model intercomparisons do not include interglacials older than the Holocene, though this is a topic of active work and future model intercomparison projects will cover the last interglacials (Otto-Bliesner et al., 2016).

It is now clear that North African precipitation was at a maximum during the mid-Holocene and during other interglacials (Ziegler et al., 2010; Rohling et al, 2015 for a complete review). Maximum Northern Hemisphere seasonality (summer perihelion-increased insolation; winter aphelion-decreased

400 insolation) has been linked to intensified summer monsoon rainfall over North Africa and also increased Mediterranean storm tracks precipitation in winters (Kutzbach et al., 2014). The analysis of PMIP3 simulations carried out in this study also demonstrate intensified African summer monsoon rainfall through the mid-Holocene, during times of enhanced winter precipitation (Fig. S6). This is consistent with Lake Ohrid proxy data where wet winters tend to occur with high contrasts in local, seasonal 405 insolation and in phase with a vigorous African summer monsoon (Wagner et al., 2019). There is also evidence for stronger seasonality in winter precipitation and P - E during interglacials in the PMIP3 simulations (Fig. S7), due to an intensifying moisture convergence in late winter, as previously suggested by palynological records from Greece and Turkey (Tzedakis, 2007; Milner et al., 2012). Previous modelling experiments demonstrate increased winter precipitation in the regions between 30

$410{ }^{\circ} \mathrm{N}$ and $45^{\circ} \mathrm{N}$ over the Mediterranean during periods of maximum orbitally forced-seasonality (Kutzbach et al., 2014). A role of obliquity forcing along with precession forcing, in increasing the seasonality and influencing Mediterranean winter rainfall, has also been proposed (Bosmans et al., 2015a).

\subsection{Contribution of western Mediterranean precipitation in sapropel deposition}

There has been a longstanding debate on the sources of freshwater contributing to the development of anoxic events and sapropel deposition in the Mediterranean in the past. The most accepted theory is that the primary source of external moisture in the Mediterranean Sea are the summer 
floods from the Nile and Central North African paleo-rivers linked to the intensification and northward $\mathrm{e}$

420 of increased winter storm tracks bringing North Atlantic-sourced moisture into the western Mediterranean basin during the past interglacials is also suggested (Toucanne et al., 2015 and references therein). In contrast, Rohling et al., (2015) refuted any external moisture source in the Mediterranean and purported that any increase in winter-time moisture in the Mediterranean was in fact recycled moisture sourced from the Mediterranean itself and, therefore, had little effect on the overall

425 hydrological budget of the basin. Our Ba/Ca-runoff record shows that the timing of increased winter rainfall during MIS 1, MIS 5e, MIS 7c and MIS 7e coincides with anoxic events in the Mediterranean that caused the deposition of organic-rich sapropels S1, S5, S8 and S9, respectively (Fig. 4) (Ziegler et al., 2010; Grant et al., 2016). Together our Ba/Ca-runoff record, along with rainfall records from Gulf of Lion which has a purely North Atlantic sourced rainfall (Pasquier et al., 2019) and Tenaghi Philippon 430 (Greece) (Ardenghi et al., 2019) and Lake Ohird (Wagner et al. 2019), support the hypothesis that the entire Northern Mediterranean borderland received increased North Atlantic moisture during the past interglacials. Additionally, our analysis of PIMP3 model simulations confirms a direct addition of late winter extra-Mediterranean (i.e. Atlantic) water into the Mediterranean Sea during the warm midHolocene, a period of northward position of the ITCZ.

435 Interestingly, these enhanced runoff events are also coeval with high rainfall periods from Levant speleothems, Soreq and Peqiin caves (Bar-Matthews et al., 2000; 2003; Bosmans et al., 2020) and increased runoff from North African river systems, including the Nile River (Rohling et al., 2002; Revel et al., 2010) (Fig. 4). This is clearly illustrated through the coincident timing of GDEC-4-2 lower salinity warm periods and the periods of sapropel deposition (Ziegler et al., 2010) shown in vertical

440 grey bars in Fig 4. The mid-Holocene model simulations analysed in this study also demonstrate enhanced North-Atlantic-sourced winter rainfall during periods of intensified African summer monsoon rainfall during the deposition of S1 (Tesi et al., 2017; Filippidi and De Lange, 2019)(see Supplementary Information for details; Fig. S6). The close correspondence of the timing of intensified African summer monsoon rainfall and North Atlantic-sourced winter rainfall, therefore, attests a close coupling between 445 low and high latitude atmospheric-oceanic processes in triggering anoxia in the Mediterranean, as is 
previously suggested (Toucanne et al., 2015; Pasquier et al., 2019). This in-phase behaviour of North A Joumal Pre-proof

interglacials during the past 1.3 Ma (Wagner et al., 2019).

Recent 'moisture tracking' modelling clearly show that local cyclogenesis is the predominant source

450 only during fall; while in late winter, the increase is attributed to enhanced moisture advection from the Atlantic (Bosmans et al., 2020). This lends further support to our findings about the existence of extraMediterranean moisture source originating from the Atlantic during winters. Such mid-latitude storm tracks originating from the North Atlantic along with the pre-conditioning of the basin by local cyclogenesis in fall (Bosmans et al., 2020), contributed to increase in freshwater, via runoff, and organic

455 fluxes into the Mediterranean Sea, with possible subsequent positive effects on the primary productivity and the marine organic matter flux to the seafloor (e.g., Rohling et al., 2015). This in turn maintained the already-disrupted hydrology of the Mediterranean (caused by increased runoff from North African rivers during periods of enhanced summer monsoon rainfall), and reduced the intermediate and deepwater ventilation. Indeed, the oceanic response to increase freshwater flux is a reduction in salinity and

460 mixed layer depth that lead to stronger stratification and less Western Mediterranean Deep Water formation (Meijer and Tuenter, 2007; Rohling et al., 2015 and reference therein).

Overall, our study provides new geochemical constraints to most debated hypothesis that penetration of direct Atlantic moisture into the western Mediterranean basin caused North Mediterranean borderland's rainfall and is a significant freshwater source in the basin (Rohling and Hilgen, 1991; Kallel et al., 2000;

465 Reale et al., 2001; Drysdale et al., 2005; Zanchetta et al., 2007; Regattieri et al., 2014; 2015; Toucanne et al., 2015). While these processes likely would have worked in concert with warming of the Mediterranean Sea to have triggered anoxia, the exact role and contribution of Atlantic origin freshwater to disrupting the western and eastern Mediterranean circulation and the process of sapropel deposition needs further investigation (e.g. Duhamel et al., 2020).

\section{Conclusions}

This work builds on the previous work by Toucanne et al., (2015), who used indirect sedimentological proxies from GDEC-4-2 to track the winter Mediterranean rainfall during the past interglacials. We test 
their hypothesis using direct geochemical proxies to better assess the variation and mechanisms of U Journal Pre-proof

475

attempt to understand the mechanism that brings about winter rainfall in the western Mediterranean is also made using PMIP3 model analysis (which are currently only available) for mid-Holocene period. Following are the salient results of this study:

i. Our geochemical data suggest increased winter runoff/ rainfall during the warm periods of the Holocene and the past two interglacials attesting the sedimentological results by Toucanne et al., (2015). Comparison of our $\mathrm{Ba} / \mathrm{Ca}$ record for river discharge with existing pollen sequences and speleothems from the central and eastern Mediterranean reveals that the interglacial wet conditions recorded off Corsica were regional in character.

ii. The intensity of the precession-controlled wintertime rainfall in the western Mediterranean was modulated by eccentricity, with times of high eccentricity characterised by higher rainfall and river outflow.

iii. The mid-Holocene model simulations supported by modern-day Mediterranean climate pattern and existing proxy studies for older interglacials, suggest that our $\mathrm{Ba} / \mathrm{Ca}$ record likely document intensified activity of the winter Mediterranean storm track of North Atlantic origin along the northern Mediterranean borderlands during the interglacials.

490 iv. Our proxy results also show that high rainfall events in the western Mediterranean occurred at times of intensified North African summer monsoon and the sapropel deposition in the Mediterranean basin.

v. The close chronological correspondence of increased river outflow and winter rainfall in the western Mediterranean and organic carbon deposition and sapropel occurrence in the eastern Mediterranean, supports a causal link. We suggest a close coupling between low and high latitude atmospheric-oceanic processes in triggering anoxia in the basin, with a contribution from three components - (a) Nile River outflow changes due to variations in African summer monsoon rainfall, (b) Mediterranean cyclogenesis, and (c) North Atlantic climaticallycontrolled winter-rainfall driving outflow changes in the western Mediterranean. 


\section{Acknowledgements}

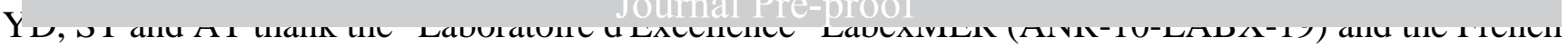

government ("Investissements d'Avenir") for support. YD was supported by a grant from the Regional Council of Brittany (SAD programme), and by the EU FP7 Marie Curie actions (PCOFUND-GA-2013-

505 609102), the PRESTIGE programme (Campus France). AT and JL acknowledge support from a NSF CAREER award (NSF EAR-1352212), and JL was also supported by a NSF AGS postdoctoral fellowship, a Chancellor's postdoctoral fellowship, and a California Alliance Postdoctoral Fellowship. We thank B. Gougeon, M. Guillermic, Y. Germain and M. Greaves (University of Cambridge) for help with the trace element analysis and Y. Baldi for collection of seawater. The authors also thank the crew and scientific members of the GOLODRILL cruise (R/V 'Bavenit' - FUGRO) for the recovery of the GDEC-4-2 borehole in the frame of the "GOLO PROGRAM", a research consortium between IFREMER, TOTAL, EXXONMOBIL and FUGRO.

\section{References}

Allen, J.R.M., Brandt, U., Brauer, A., Hubberten, H.-W., Huntley, B., Keller, J., Kraml, M., Mackensen, A., Mingram, J., Negendank, J.F.W., 1999. Rapid environmental changes in southern Europe during the last glacial period. Nature 400, 740-743.

Allen, P.A., 2008. Time scales of tectonic landscapes and their sediment routing systems. Geological Society, London, Special Publications 296, 7-28.

Amore, F.O., Flores, J.A., Voelker, A.H.L., Lebreiro, S.M., Palumbo, E., Sierro, F.J., 2012. A Middle Pleistocene Northeast Atlantic coccolithophore record: Paleoclimatology and paleoproductivity aspects. $\quad$ Marine $\quad$ Micropaleontology $\quad 90-91, \quad 44-59$. doi:https://doi.org/10.1016/j.marmicro.2012.03.006

Ardenghi, N., Mulch, A., Koutsodendris, A., Pross, J., Kahmen, A., Niedermeyer, E.M., 2019. Temperature and moisture variability in the eastern Mediterranean region during Marine Isotope Stages 11-10 based on biomarker analysis of the Tenaghi Philippon peat deposit. Quaternary Science Reviews 225, 105977. doi:https://doi.org/10.1016/j.quascirev.2019.105977 
Ariztegui, D., Asioli, A., Lowe, J.J., Trincardi, F., Vigliotti, L., Tamburini, F., Chondrogianni, C., Journal Pre-proof d, F., 2000. Palaeoclimate and the formation of sapropel S1: inferences from Late Quaternary lacustrine and marine sequences in the central Mediterranean region. Palaeogeography, Palaeoclimatology, Palaeoecology 158, 215-240. doi:10.1016/S0031-0182(00)00051-1

Bar-Matthews, M., Ayalon, A., Kaufman, A., 2000. Timing and hydrological conditions of Sapropel events in the Eastern Mediterranean, as evident from speleothems, Soreq cave, Israel. Chemical Geology 169, 145-156. doi:10.1016/S0009-2541(99)00232-6

535 Bar-Matthews, M., Ayalon, A., Gilmour, M., Matthews, A., Hawkesworth, C.J., 2003. Sea-land oxygen isotopic relationships from planktonic foraminifera and speleothems in the Eastern Mediterranean region and their implication for paleorainfall during interglacial intervals. A Special Issue Dedicated to Robert Clayton 67, 3181-3199. doi:10.1016/S0016-7037(02)01031-1

Bard, E., Delaygue, G., Rostek, F., Antonioli, F., Silenzi, S., Schrag, D.P., 2002. Hydrological conditions over the western Mediterranean basin during the deposition of the cold Sapropel 6 (ca. 175 kyr BP). Earth and Planetary Science Letters 202, 481-494.

Barker, S., Elderfield, H., 2002. Foraminiferal calcification response to glacial-interglacial changes in atmospheric CO2. Science 297, 833-836.

Barker, S., Greaves, M., Elderfield, H., 2003. A study of cleaning procedures used for foraminiferal $\mathrm{Mg} / \mathrm{Ca}$ paleothermometry. Geochemistry, Geophysics, Geosystems 4.

Barker, S., Knorr, G., Edwards, R.L., Parrenin, F., Putnam, A.E., Skinner, L.C., Wolff, E., Ziegler, M., 2011. 800,000 Years of Abrupt Climate Variability. Science 334, 347. doi:10.1126/science. 1203580

Barker, S., Knorr, G., Conn, S., Lordsmith, S., Newman, D., Thornalley, D., 2019. Early Interglacial Legacy of Deglacial Climate Instability. Paleoceanography and Paleoclimatology 34, 1455-1475. doi:10.1029/2019PA003661

Bemis, B.E., Spero, H.J., Bijma, J., Lea, D.W., 1998. Reevaluation of the oxygen isotopic composition of planktonic foraminifera: Experimental results and revised paleotemperature equations. Paleoceanography 13, 150-160. doi:10.1029/98PA00070 
555 Bengtsson, L., Hodges, K.I., Keenlyside, N., 2009. Will Extratropical Storms Intensify in a Warmer Journal Pre-proof

Bosmans, J.H.C., Drijfhout, S.S., Tuenter, E., Hilgen, F.J., Lourens, L.J., Rohling, E.J., 2015a. Precession and obliquity forcing of the freshwater budget over the Mediterranean. Quaternary Science Reviews 123, 16-30. doi:https://doi.org/10.1016/j.quascirev.2015.06.008

560 Bosmans, J.H.C., Drijfhout, S.S., Tuenter, E., Hilgen, F.J., Lourens, L.J., 2015b. Response of the North African summer monsoon to precession and obliquity forcings in the EC-Earth GCM. Climate dynamics 44, 279-297.

Bosmans, J.H.C., Ent, R.J. van der, Haarsma, R.J., Drijfhout, S.S., Hilgen, F.J., 2020. Precession- and Obliquity-Induced Changes in Moisture Sources for Enhanced Precipitation Over the Mediterranean Sea. Paleoceanography and Paleoclimatology 35, e2019PA003655. doi:10.1029/2019PA003655

Boussetta, S., Bassinot, F., Sabbatini, A., Caillon, N., Nouet, J., Kallel, N., Rebaubier, H., Klinkhammer, G., Labeyrie, L., 2011. Diagenetic Mg-rich calcite in Mediterranean sediments: Quantification and impact on foraminiferal Mg/Ca thermometry. Marine Geology 280, 195-204. doi:https://doi.org/10.1016/j.margeo.2010.12.011

Boyle, E., Rosenthal, Y., 1996. Chemical hydrography of the South Atlantic during the last glacial maximum: Cd vs. $\delta 13 \mathrm{C}$. In: The South Atlantic. Springer, pp. 423-443.

Boyle, E.A., 1983. Manganese carbonate overgrowths on foraminifera tests. Geochimica et Cosmochimica Acta 47, 1815-1819.

575 Braconnot, P., Harrison, S.P., Otto-Bliesner, B., Abe-Ouchi, A., Jungclaus, J., Peterschmitt, J.Y., 2011. The Paleoclimate Modeling Intercomparison Project contribution to CMIP5. CLIVAR Exchanges $56,15-19$.

Braconnot, P., Harrison, S.P., Kageyama, M., Bartlein, P.J., Masson-Delmotte, V., Abe-Ouchi, A., Otto-Bliesner, B., Zhao, Y., 2012. Evaluation of climate models using palaeoclimatic data. Nature 580 Climate Change 2, 417.

Brayshaw, D.J., Rambeau, C.M.C., Smith, S.J., 2011. Changes in Mediterranean climate during the Holocene: Insights from global and regional climate modelling. The Holocene 21, 15-31. 
M., Abreu, V., 2013. Inferring denudation variations from the sediment record; an example of the last glacial cycle record of the Golo Basin and watershed, East Corsica, western Mediterranean sea. Basin Research 25, 197-218.

Carrión, J.S., 2002. Patterns and processes of Late Quaternary environmental change in a montane region of southwestern Europe. Quaternary Science Reviews 21, 2047-2066. doi:10.1016/S02773791(02)00010-0

Celle-Jeanton, H., Travi, Y., Blavoux, B., 2001. Isotopic typology of the precipitation in the Western Mediterranean Region at three different time scales. Geophysical Research Letters 28, 1215-1218. doi:10.1029/2000GL012407

Cisneros, M., Cacho, I., Frigola, J., Canals, M., Masqué, P., Martrat, B., Casado, M., Grimalt, J.O., Pena, L.D., Margaritelli, G., Lirer, F., 2016. Sea surface temperature variability in the centralwestern Mediterranean Sea during the last 2700 years: a multi-proxy and multi-record approach. Clim. Past 12, 849-869. doi:10.5194/cp-12-849-2016

Coffey, M., Dehairs, F., Collette, O., Luther, G., Church, T., Jickells, T., 1997. The behaviour of dissolved barium in estuaries. Estuarine, Coastal and Shelf Science 45, 113-121.

Digerfeldt, G., Sandgren, P., Olsson, S., 2007. Reconstruction of Holocene lake-level changes in Lake Xinias, central Greece. The Holocene 17, 361-367.

Dormoy, I., Peyron, O., Combourieu Nebout, N., Goring, S., Kotthoff, U., Magny, M., Pross, J., 2009. Terrestrial climate variability and seasonality changes in the Mediterranean region between 15000 and 4000 years BP deduced from marine pollen records. Climate of the Past 5, 615-632.

605 Doss, W., Marchitto, T.M., 2013. Glacial deep ocean sequestration of CO 2 driven by the eastern equatorial Pacific biologic pump. Earth and Planetary Science Letters 377, 43-54.

Drysdale, R.N., Zanchetta, G., Hellstrom, J.C., Fallick, A.E., Zhao, J., 2005. Stalagmite evidence for the onset of the Last Interglacial in southern Europe at $129 \pm 1$ ka. Geophysical Research Letters 32, n/a-n/a. doi:10.1029/2005GL024658

610 Duhamel, M., Colin, C., Revel, M., Siani, G., Dapoigny, A., Douville, E., Wu, J., Zhao, Y., Liu, Z., 
Montagna, P., 2020. Variations in eastern Mediterranean hydrology during the last climatic cycle Journal Pre-proof 5.

doi:https://doi.org/10.1016/j.quascirev.2020.106306

Eastwood, W.J., Leng, M.J., Roberts, N., Davis, B., 2007. Holocene climate change in the eastern

Mediterranean region: a comparison of stable isotope and pollen data from Lake Gölhisar, southwest Turkey. Journal of Quaternary Science 22, 327-341.

Ezat, M.M., Rasmussen, T.L., Groeneveld, J., 2016. Reconstruction of hydrographic changes in the southern Norwegian Sea during the past $135 \mathrm{kyr}$ and the impact of different foraminiferal $\mathrm{Mg} / \mathrm{Ca}$ cleaning protocols. Geochemistry, Geophysics, Geosystems 17, 3420-3436. doi:10.1002/2016GC006325

Ferguson, J.E., Henderson, G.M., Kucera, M., Rickaby, R.E.M., 2008. Systematic change of foraminiferal $\mathrm{Mg} / \mathrm{Ca}$ ratios across a strong salinity gradient. Earth and Planetary Science Letters 265, 153-166. doi:https://doi.org/10.1016/j.eps1.2007.10.011

Filippidi, A., Lange, G.J. De, 2019. Eastern Mediterranean Deep Water Formation During Sapropel S1:

A Reconstruction Using Geochemical Records Along a Bathymetric Transect in the Adriatic Outflow Region. Paleoceanography and Paleoclimatology 34, 409-429. doi:10.1029/2018PA003459

Fletcher, W.J., Sánchez Goñi, M.F., 2008. Orbital- and sub-orbital-scale climate impacts on vegetation of the western Mediterranean basin over the last 48,000 yr. Quaternary Research 70, 451-464. doi:https://doi.org/10.1016/j.yqres.2008.07.002

Grant, K.M., Grimm, R., Mikolajewicz, U., Marino, G., Ziegler, M., Rohling, E.J., 2016. The timing of Mediterranean sapropel deposition relative to insolation, sea-level and African monsoon changes. Quaternary Science Reviews 140, 125-141.

Guiot, J., Cramer, W., 2016. Climate change: The 2015 Paris Agreement thresholds and Mediterranean basin ecosystems. Science 354, 465. doi:10.1126/science.aah5015

Harrison, S.P., Bartlein, P.J., Izumi, K., Li, G., Annan, J., Hargreaves, J., Braconnot, P., Kageyama, M., 2015. Evaluation of CMIP5 palaeo-simulations to improve climate projections. Nature Climate Change 5, 735 . 
Hönisch, B., Allen, K.A., Russell, A.D., Eggins, S.M., Bijma, J., Spero, H.J., Lea, D.W., Yu, J., 2011.

doi:10.1016/j.marmicro.2011.01.003

Hoogakker, B.A.A., Klinkhammer, G.P., Elderfield, H., Rohling, E.J., Hayward, C., 2009. Mg/Ca paleothermometry in high salinity environments. Earth and Planetary Science Letters 284, 583589.

645 Hoskins, B.J., Hodges, K.I., 2002. New Perspectives on the Northern Hemisphere Winter Storm Tracks. Journal of the Atmospheric Sciences 59, 1041-1061. doi:10.1175/15200469(2002)059<1041:NPOTNH>2.0.CO;2

Hurrell, J.W., 1995. Decadal Trends in the North Atlantic Oscillation: Regional Temperatures and Precipitation. Science 269, 676 LP - 679. doi:10.1126/science.269.5224.676

650 Kallel, N., Duplessy, J.-C., Labeyrie, L., Fontugne, M., Paterne, M., Montacer, M., 2000. Mediterranean pluvial periods and sapropel formation over the last 200000 years. Palaeogeography, Palaeoclimatology, Palaeoecology 157, 45-58. doi:https://doi.org/10.1016/S0031-0182(99)001492

Kandiano, E.S., Bauch, H.A., Fahl, K., 2014. Last interglacial surface water structure in the western Mediterranean (Balearic) Sea: Climatic variability and link between low and high latitudes. Global and Planetary Change 123, 67-76.

Kuhlemann, J., Rohling, E.J., Krumrei, I., Kubik, P., Ivy-Ochs, S., Kucera, M., 2008. Regional Synthesis of Mediterranean Atmospheric Circulation During the Last Glacial Maximum. Science 321, 1338 LP - 1340.

660 Kutzbach, J.E., Chen, G., Cheng, H., Edwards, R.L., Liu, Z., 2014. Potential role of winter rainfall in explaining increased moisture in the Mediterranean and Middle East during periods of maximum orbitally-forced insolation seasonality. Climate dynamics 42, 1079-1095.

Lascaratos, A., Roether, W., Nittis, K., Klein, B., 1999. Recent changes in deep water formation and spreading in the eastern Mediterranean Sea: a review. Progress in oceanography 44, 5-36.

665 Lawson, I.T., Al-Omari, S., Tzedakis, P.C., Bryant, C.L., Christaniss, K., 2005. Lateglacial and Holocene vegetation history at Nisi Fen and the Boras mountains, northern Greece. The Holocene 
$15,873-887$.

$\mathrm{L}$

$55,3321-3331$.

670 Lea, D.W., Spero, H.J., 1994. Assessing the reliability of paleochemical tracers: Barium uptake in the shells of planktonic foraminifera. Paleoceanography 9, 445-452. doi:10.1029/94PA00151

Lisiecki, L.E., Raymo, M.E., 2005. A Pliocene-Pleistocene stack of 57 globally distributed benthic $\delta 180$ records. Paleoceanography 20. doi:10.1029/2004PA001071

Lohmann, G., 2017. Atmospheric bridge on orbital time scales. Theoretical and Applied Climatology 128, 709-718. doi:10.1007/s00704-015-1725-2

López-Moreno, J.I., Vicente-Serrano, S.M., Morán-Tejeda, E., Lorenzo-Lacruz, J., Kenawy, A., Beniston, M., 2011. Effects of the North Atlantic Oscillation (NAO) on combined temperature and precipitation winter modes in the Mediterranean mountains: Observed relationships and projections for the 21st century. Global and Planetary Change 77, 62-76. doi:https://doi.org/10.1016/j.gloplacha.2011.03.003

Magny, M., Beaulieu, J.-L. De, Drescher-Schneider, R., Vannière, B., Walter-Simonnet, A.-V., Miras, Y., Millet, L., Bossuet, G., Peyron, O., Brugiapaglia, E., 2007. Holocene climate changes in the central Mediterranean as recorded by lake-level fluctuations at Lake Accesa (Tuscany, Italy). Quaternary Science Reviews 26, 1736-1758.

685 Magny, M., Bossuet, G., Ruffaldi, P., Leroux, A., Mouthon, J., 2011. Orbital imprint on Holocene palaeohydrological variations in west-central Europe as reflected by lake-level changes at Cerin (Jura Mountains, eastern France). Journal of Quaternary Science 26, 171-177.

Magny, M., Joannin, S., Galop, D., Vannière, B., Haas, J.N., Bassetti, M., Bellintani, P., Scandolari, R., Desmet, M., 2012. Holocene palaeohydrological changes in the northern Mediterranean borderlands as reflected by the lake-level record of Lake Ledro, northeastern Italy. Quaternary Research 77, 382-396.

Magny, M., Combourieu-Nebout, N., Beaulieu, J.L. de, Bout-Roumazeilles, V., Colombaroli, D., Desprat, S., Francke, A., Joannin, S., Ortu, E., Peyron, O., Revel, M., Sadori, L., Siani, G., Sicre, M.A., Samartin, S., Simonneau, A., Tinner, W., Vannière, B., Wagner, B., Zanchetta, G., 
North-south palaeohydrological contrasts in the central Mediterranean during the Holocene: tentative synthesis and working hypotheses. Climate of the Past 9, 2043-2071. doi:10.5194/cp-92043-2013

700 Malanotte-Rizzoli, B., M.B., Salvatore, M., M., 2003. The Levantine Intermediate Water Experiment (LIWEX) Group: Levantine basin-A laboratory for multiple water mass formation processes. Journal of Geophysical Research: Oceans 108. doi:10.1029/2002JC001643

Marchitto, T.M., 2006. Precise multielemental ratios in small foraminiferal samples determined by sector field ICP-MS. Geochemistry, Geophysics, Geosystems 7, n/a-n/a. doi:10.1029/2005GC001018

Marino, G., Rohling, E.J., Rijpstra, W.I.C., Sangiorgi, F., Schouten, S., Damsté, J.S.S., 2007. Aegean Sea as driver of hydrographic and ecological changes in the eastern Mediterranean. Geology 35, $675-678$.

Marino, G., Rohling, E.J., Rodríguez-Sanz, L., Grant, K.M., Heslop, D., Roberts, A.P., Stanford, J.D., Yu, J., 2015. Bipolar seesaw control on last interglacial sea level. Nature 522, 197-201.

Marr, J.P., Carter, L., Bostock, H.C., Bolton, A., Smith, E., 2013. Southwest Pacific Ocean response to a warming world: Using $\mathrm{Mg} / \mathrm{Ca}, \mathrm{Zn} / \mathrm{Ca}$, and $\mathrm{Mn} / \mathrm{Ca}$ in foraminifera to track surface ocean water masses during the last deglaciation. Paleoceanography 28, 347-362. doi:10.1002/palo.20032

Martínez-Ruiz, F., Paytan, A., Kastner, M., González-Donoso, J.M., Linares, D., Bernasconi, S.M., Jimenez-Espejo, F.J., 2003. A comparative study of the geochemical and mineralogical characteristics of the S1 sapropel in the western and eastern Mediterranean. Palaeogeography, Palaeoclimatology, Palaeoecology 190, 23-37. doi:https://doi.org/10.1016/S0031-0182(02)005977

Martrat, B., Jimenez-Amat, P., Zahn, R., Grimalt, J.O., 2014. Similarities and dissimilarities between the last two deglaciations and interglaciations in the North Atlantic region. Quaternary Science Reviews 99, 122-134.

Marzocchi, A., Flecker, R., Lunt, D.J., Krijgsman, W., Hilgen, F.J., 2019. Precessional drivers of late 
Miocene Mediterranean sedimentary sequences: African summer monsoon and Atlantic winter

725 McConnell, M.C., Thunell, R.C., 2005. Calibration of the planktonic foraminiferal $\mathrm{Mg} / \mathrm{Ca}$ paleothermometer: Sediment trap results from the Guaymas Basin, Gulf of California. Paleoceanography 20.

Meijer, P.T., Tuenter, E., 2007. The effect of precession-induced changes in the Mediterranean freshwater budget on circulation at shallow and intermediate depth. Journal of Marine Systems 68, 349-365. doi:https://doi.org/10.1016/j.jmarsys.2007.01.006

Milner, A.M., Collier, R.E.L., Roucoux, K.H., Müller, U.C., Pross, J., Kalaitzidis, S., Christanis, K., Tzedakis, P.C., 2012. Enhanced seasonality of precipitation in the Mediterranean during the early part of the Last Interglacial. Geology 40, 919-922.

Olsen, J., Anderson, N.J., Knudsen, M.F., 2012. Variability of the North Atlantic Oscillation over the past 5,200 years. Nature Geoscience 5, 808 .

Otto-Bliesner, B.L., Braconnot, P., Harrison, S.P., Lunt, D.J., Abe-Ouchi, A., Albani, S., Bartlein, P.J., Capron, E., Carlson, A.E., Dutton, A., Fischer, H., Goelzer, H., Govin, A., Haywood, A., Joos, F., Legrande, A.N., Lipscomb, W.H., Lohmann, G., Mahowald, N., Nehrbass-Ahles, C., Pausata, F.S.R., Peterschmitt, J.-Y., Phipps, S., Renssen, H., 2016. The PMIP4 contribution to CMIP6 - Part 2: Two Interglacials, Scientific Objective and Experimental Design for Holocene and Last Interglacial Simulations. Geoscientific Model Development Discussions 2016, 1-36. doi:10.5194/gmd-2016-279

Pachauri, R.K., Allen, M.R., Barros, V.R., Broome, J., Cramer, W., Christ, R., Church, J.A., Clarke, L., Dahe, Q., Dasgupta, P., IPCC Fifth report, 2014, 2014. Climate change 2014: synthesis report. Contribution of Working Groups I, II and III to the fifth assessment report of the Intergovernmental Panel on Climate Change. IPCC, Geneva, Switzerland.

Pasquier, V., Toucanne, S., Sansjofre, P., Dixit, Y., Revillon, S., Mokeddem, Z., Rabineau, M., 2019. Organic matter isotopes reveal enhanced rainfall activity in Northwestern Mediterranean borderland during warm substages of the last 200 kyr. Quaternary Science Reviews 205, 182-192. doi:https://doi.org/10.1016/j.quascirev.2018.12.007 
Pena, L.D., Calvo, E., Cacho, I., Eggins, S., Pelejero, C., 2005. Identification and removal of Mn-MgJournal Pre-proof e

reconstructions. Geochemistry, Geophysics, Geosystems 6. doi:10.1029/2005GC000930

Peyron, O., Goring, S., Dormoy, I., Kotthoff, U., Pross, J., Beaulieu, J.-L. De, Drescher-Schneider, R., Vannière, B., Magny, M., 2011. Holocene seasonality changes in the central Mediterranean region reconstructed from the pollen sequences of Lake Accesa (Italy) and Tenaghi Philippon (Greece). The Holocene 21, 131-146.

Peyron, O., Combourieu-Nebout, N., Brayshaw, D., Goring, S., Andrieu-Ponel, V., Desprat, S., Fletcher, W., Gambin, B., Ioakim, C., Joannin, S., Kotthoff, U., Kouli, K., Montade, V., Pross, J., Sadori, L., Magny, M., 2017. Precipitation changes in the Mediterranean basin during the Holocene from terrestrial and marine pollen records: a model-data comparison. Climate of the Past 13, 249-265. doi:10.5194/cp-13-249-2017

Pickarski, N., Litt, T., 2017. A new high-resolution pollen sequence at Lake Van, Turkey: insights into penultimate interglacial-glacial climate change on vegetation history. Climate of the Past 13, 689.

765 Pinardi, N., Masetti, E., 2000. Variability of the large scale general circulation of the Mediterranean Sea from observations and modelling: a review. Palaeogeography, Palaeoclimatology, Palaeoecology $158,153-173$.

Pujol, C., Grazzini, C.V., 1995. Distribution patterns of live planktic foraminifers as related to regional hydrography and productive systems of the Mediterranean Sea. Marine Micropaleontology 25, 770 $187-217$.

Raden, U.J. van, Groeneveld, J., Raitzsch, M., Kucera, M., 2011. Mg/Ca in the planktonic foraminifera Globorotalia inflata and Globigerinoides bulloides from Western Mediterranean plankton tow and $\begin{array}{llll}\text { core top } \quad \text { samples. Marine } \quad \text { Micropaleontology } & \text { 78, }\end{array}$ doi:https://doi.org/10.1016/j.marmicro.2010.11.002

775 Rasmussen, S.O., Andersen, K.K., Svensson, A.M., Steffensen, J.P., Vinther, B.M., Clausen, H.B., Siggaard-Andersen, M., Johnsen, S.J., Larsen, L.B., Dahl-Jensen, D., 2006. A new Greenland ice core chronology for the last glacial termination. Journal of Geophysical Research: Atmospheres 111. 
Reale, O., Feudale, L., Turato, B., 2001. Evaporative moisture sources during a sequence of floods in 780

doi:10.1029/2000GL012379

Reed, J.M., Stevenson, A.C., Juggins, S., 2001. A multi-proxy record of Holocene climatic change in southwestern Spain: the Laguna de Medina, Cádiz. The Holocene 11, 707-719.

Regattieri, E., Zanchetta, G., Drysdale, R.N., Isola, I., Hellstrom, J.C., Roncioni, A., 2014. A continuous stable isotope record from the penultimate glacial maximum to the Last Interglacial (159-121ka) from Tana Che Urla Cave (Apuan Alps, central Italy). Quaternary Research 82, 450-461.

Regattieri, E., Giaccio, B., Zanchetta, G., Drysdale, R.N., Galli, P., Nomade, S., Peonace, E., Wulf, S., 2015. Hydrological variability over the Apennines during the Early Last Glacial precession minimum, as revealed by a stable isotope record from Sulmona basin, Central Italy. Journal of Quaternary Science 30, 19-31. doi:10.1002/jqs.2755

Revel, M., Ducassou, E., Grousset, F.E., Bernasconi, S.M., Migeon, S., Revillon, S., Mascle, J., Murat, A., Zaragosi, S., Bosch, D., 2010. 100,000 Years of African monsoon variability recorded in sediments of the Nile margin. Quaternary Science Reviews 29, 1342-1362. doi:https://doi.org/10.1016/j.quascirev.2010.02.006

795 Robinson, A.R., Malanotte-Rizzoli, P., Hecht, A., Michelato, A., Roether, W., Theocharis, A., Ünlüata, Ü., Pinardi, N., Artegiani, A., Bergamasco, A., Bishop, J., Brenner, S., Christianidis, S., Gacic, M., Georgopoulos, D., Golnaraghi, M., Hausmann, M., Junghaus, H.-G., Lascaratos, A., Latif, M.A., Leslie, W.G., Lozano, C.J., Og،uz, T., Özsoy, E., Papageorgiou, E., Paschini, E., Rozentroub, Z., Sansone, E., Scarazzato, P., Schlitzer, R., Spezie, G.-C., Tziperman, E., Zodiatis, G., Athanassiadou, L., Gerges, M., Osman, M., 1992. General circulation of the Eastern Mediterranean. Earth-Science Reviews 32, 285-309. doi:https://doi.org/10.1016/00128252(92)90002-B

Rodríguez-Sanz, L., Bernasconi, S.M., Marino, G., Heslop, D., Müller, I.A., Fernandez, A., Grant, K.M., Rohling, E.J., 2017. Penultimate deglacial warming across the Mediterranean Sea revealed by clumped isotopes in foraminifera. Scientific Reports 7, 16572. doi:10.1038/s41598-017-165286 
Rohling, E.J., Hilgen, F.J., 1991. The eastern Mediterranean climate at times of sapropel formation: a Journal Pre-proof

Rohling, E.J., Cane, T.R., Cooke, S., Sprovieri, M., Bouloubassi, I., Emeis, K.C., Schiebel, R., Kroon, D., Jorissen, F.J., Lorre, A., 2002. African monsoon variability during the previous interglacial maximum. Earth and Planetary Science Letters 202, 61-75.

Rohling, E.J., Marino, G., Grant, K.M., 2015. Mediterranean climate and oceanography, and the periodic development of anoxic events (sapropels). Earth-Science Reviews 143, 62-97.

Rossignol-Strick, M., 1983. African monsoons, an immediate climate response to orbital insolation. Nature 304, 46-49. doi:10.1038/304046a0

Rossignol-Strick, M., Roy, P.D., Singhvi, A.K., 1985. Mediterranean Quaternary sapropels, an immediate response of the African monsoon to variation of insolation. Palaeogeography, palaeoclimatology, palaeoecology 19, 32-44. doi:10.1016/j.recqb.2016.02.004

Sierro, F.J., Ledesma, S., Flores, J.-A., Torrescusa, S., Olmo, W.M. del, 2000. Sonic and gamma-ray astrochronology: Cycle to cycle calibration of Atlantic climatic records to Mediterranean sapropels and astronomical oscillations. Geology 28, 695-698.

Skinner, L.C., Shackleton, N.J., Elderfield, H., 2003. Millennial-scale variability of deep-water temperature and $\delta 180 d w$ indicating deep-water source variations in the Northeast Atlantic, 0-34 cal. ka BP. Geochemistry, Geophysics, Geosystems 4, n/a-n/a. doi:10.1029/2003GC000585

825 Sprovieri, M., d'Alcalà, M.R., Manta, D.S., Bellanca, A., Neri, R., Lirer, F., Taberner, C., Pueyo, J.J., Sammartino, S., 2008. Ba/Ca evolution in water masses of the Mediterranean late Neogene. Paleoceanography and Paleoclimatology 23.

Svensson, A., Andersen, K.K., Bigler, M., Clausen, H.B., Dahl-Jensen, D., Davies, S.M., Johnsen, S.J., Muscheler, R., Parrenin, F., Rasmussen, S.O., 2008. A 60000 year Greenland stratigraphic ice core chronology. Climate of the Past 4, 47-57.

Sweet, M.L., Gaillot, G.T., Jouet, G., Rittenour, T.M., Toucanne, S., Marsset, T., Blum, M.D., 2019. Sediment routing from shelf to basin floor in the Quaternary Golo System of Eastern Corsica, France, western Mediterranean Sea. GSA Bulletin. doi:10.1130/B35181.1

Taylor, K.E., Stouffer, R.J., Meehl, G.A., 2011. An Overview of CMIP5 and the Experiment Design. 
Montagna, P., Trincardi, F., 2017. Large-scale response of the Eastern Mediterranean thermohaline circulation to African monsoon intensification during sapropel S1 formation. Quaternary Science Reviews 159, 139-154. doi:https://doi.org/10.1016/j.quascirev.2017.01.020

840 Toucanne, S., Jouet, G., Ducassou, E., Bassetti, M.-A., Dennielou, B., Angue Minto’o, C.M., Lahmi, M., Touyet, N., Charlier, K., Lericolais, G., Mulder, T., 2012. A 130,000-year record of Levantine Intermediate Water flow variability in the Corsica Trough, western Mediterranean Sea. Quaternary Science Reviews 33, 55-73. doi:https://doi.org/10.1016/j.quascirev.2011.11.020

Toucanne, S., Minto’o, C.M.A., Fontanier, C., Bassetti, M.-A., Jorry, S.J., Jouet, G., 2015. Tracking 845 rainfall in the northern Mediterranean borderlands during sapropel deposition. Quaternary Science Reviews 129, 178-195.

Trigo, I.F., Bigg, G.R., Davies, T.D., 2002. Climatology of cyclogenesis mechanisms in the Mediterranean. Monthly Weather Review 130, 549-569.

Tuenter, E., Weber, S.L., Hilgen, F.J., Lourens, L.J., 2003. The response of the African summer 850 monsoon to remote and local forcing due to precession and obliquity. Global and Planetary Change 36, 219-235. doi:https://doi.org/10.1016/S0921-8181(02)00196-0

Turner, R., Roberts, N., Jones, M.D., 2008. Climatic pacing of Mediterranean fire histories from lake sedimentary microcharcoal. Global and Planetary Change 63, 317-324.

Tzedakis, P.C., 2007. Seven ambiguities in the Mediterranean palaeoenvironmental narrative. Quaternary Science Reviews 26, 2042-2066.

Tzedakis, P.C., Drysdale, R.N., Margari, V., Skinner, L.C., Menviel, L., Rhodes, R.H., Taschetto, A.S., Hodell, D.A., Crowhurst, S.J., Hellstrom, J.C., Fallick, A.E., Grimalt, J.O., McManus, J.F., Martrat, B., Mokeddem, Z., Parrenin, F., Regattieri, E., Roe, K., Zanchetta, G., 2018. Enhanced climate instability in the North Atlantic and southern Europe during the Last Interglacial. Nature Communications 9, 4235. doi:10.1038/s41467-018-06683-3

Valero, L., Garcés, M., Cabrera, L., Costa, E., Sáez, A., 2014. 20 Myr of eccentricity paced lacustrine cycles in the Cenozoic Ebro Basin. Earth and Planetary Science Letters 408, 183-193. 
doi:https://doi.org/10.1016/j.eps1.2014.10.007

V

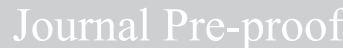

Sadori, L., Wilke, T., Zanchetta, G., Albrecht, C., Bertini, A., Combourieu-Nebout, N., Cvetkoska, A., Giaccio, B., Grazhdani, A., Hauffe, T., Holtvoeth, J., Joannin, S., Jovanovska, E., Just, J., Kouli, K., Kousis, I., Koutsodendris, A., Krastel, S., Lagos, M., Leicher, N., Levkov, Z., Lindhorst, K., Masi, A., Melles, M., Mercuri, A.M., Nomade, S., Nowaczyk, N., Panagiotopoulos, K., Peyron, O., Reed, J.M., Sagnotti, L., Sinopoli, G., Stelbrink, B., Sulpizio, R., Timmermann, A., Tofilovska, S., Torri, P., Wagner-Cremer, F., Wonik, T., Zhang, X., 2019. Mediterranean winter rainfall in phase with African monsoons during the past 1.36 million years. Nature 573, 256-260. doi:10.1038/s41586-019-1529-0

Weldeab, S., Lea, D.W., Schneider, R.R., Andersen, N., 2007. 155,000 years of West African monsoon and ocean thermal evolution. science 316, 1303-1307.

875 Wu, J., Liu, Z., Stuut, J.-B.W., Zhao, Y., Schirone, A., Lange, G.J. de, 2017. North-African paleodrainage discharges to the central Mediterranean during the last 18,000 years: A multiproxy characterization. Quaternary Science Reviews 163, 95-113. doi:https://doi.org/10.1016/j.quascirev.2017.03.015

Zanchetta, G., Drysdale, R.N., Hellstrom, J.C., Fallick, A.E., Isola, I., Gagan, M.K., Pareschi, M.T., 2007. Enhanced rainfall in the Western Mediterranean during deposition of sapropel S1: stalagmite evidence from Corchia cave (Central Italy). Quaternary Science Reviews 26, 279-286. doi:10.1016/j.quascirev.2006.12.003

Ziegler, M., Tuenter, E., Lourens, L.J., 2010. The precession phase of the boreal summer monsoon as viewed from the eastern Mediterranean (ODP Site 968). Quaternary Science Reviews 29, 14811490.

Zielhofer, C., Fletcher, W.J., Mischke, S., Batist, M. De, Campbell, J.F.E., Joannin, S., Tjallingii, R., Hamouti, N. El, Junginger, A., Stele, A., 2017. Atlantic forcing of Western Mediterranean winter rain minima during the last 12,000 years. Quaternary Science Reviews 157, 29-51. 

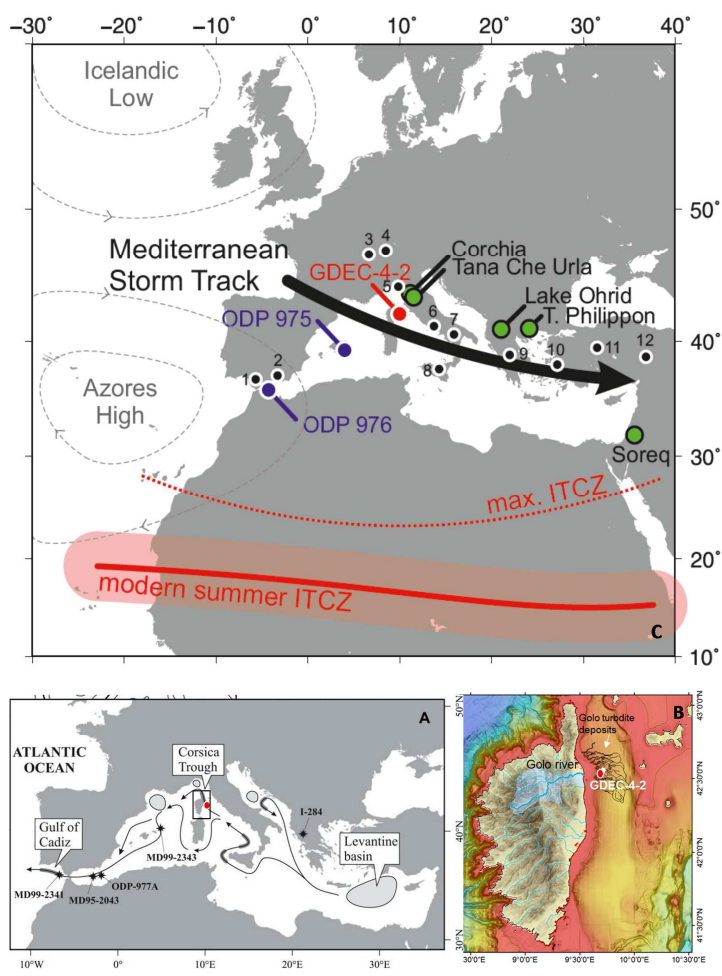

Figure 1: Location of GDEC-4-2 (red) in the Northern Tyrrhenian Sea in the Mediterranean basin. (A) Hydrography of the 895 Mediterranean Sea with the present-day Levantime Intermediate Water (LIW) circulation from Toucanne et al., 2012; (B) Regional bathymetry and hydrography around Corsica showing GDEC-4-2; (C) GDEC4-2 and other marine (blue) and terrestrial archives (green). Numbers and black dots denote the lake level records used to compare results with model simulations in Figure 5. 1) Lake Medina in southern Spain (Reed et al., 2001); (2) Lake Siles in southern Spain (Carrión, 2002); (3) Lake Cerin (Magny et al., 2011); (4) Lake Ledro in northern Italy (Magny et al., 2012); (5) Lake Accesa in central

900 Italy (Magny et al., 2007); (6) Lake Grande diMonticchio in Basilicata, southern Italy (Allen et al., 1999); (7) Lake Albano and Lake Nema (Ariztegui et al., 2000); (8) Lake Preola in Sicily (Magny et al., 2011); (9) Lake Xinias in northern Greece (Digerfeldt et al., 2007); (10) Lake Golhisar in south-western Turkey (Eastwood et al., 2007); (11) Lake Eski Acigol in central Turkey (Turner et al., 2008); (12) Lake Van in Turkey (Pickarski and Litt, 2017). Red band and red dotted line denotes the extent of modern summer ITCZ and the maximum northward reach of ITCZ in the past respectively (Tuenter et 905 al., 2003). Also shown are the sea-level pressures in North Atlantic and general direction of Mediterranean storm tracks (black). 


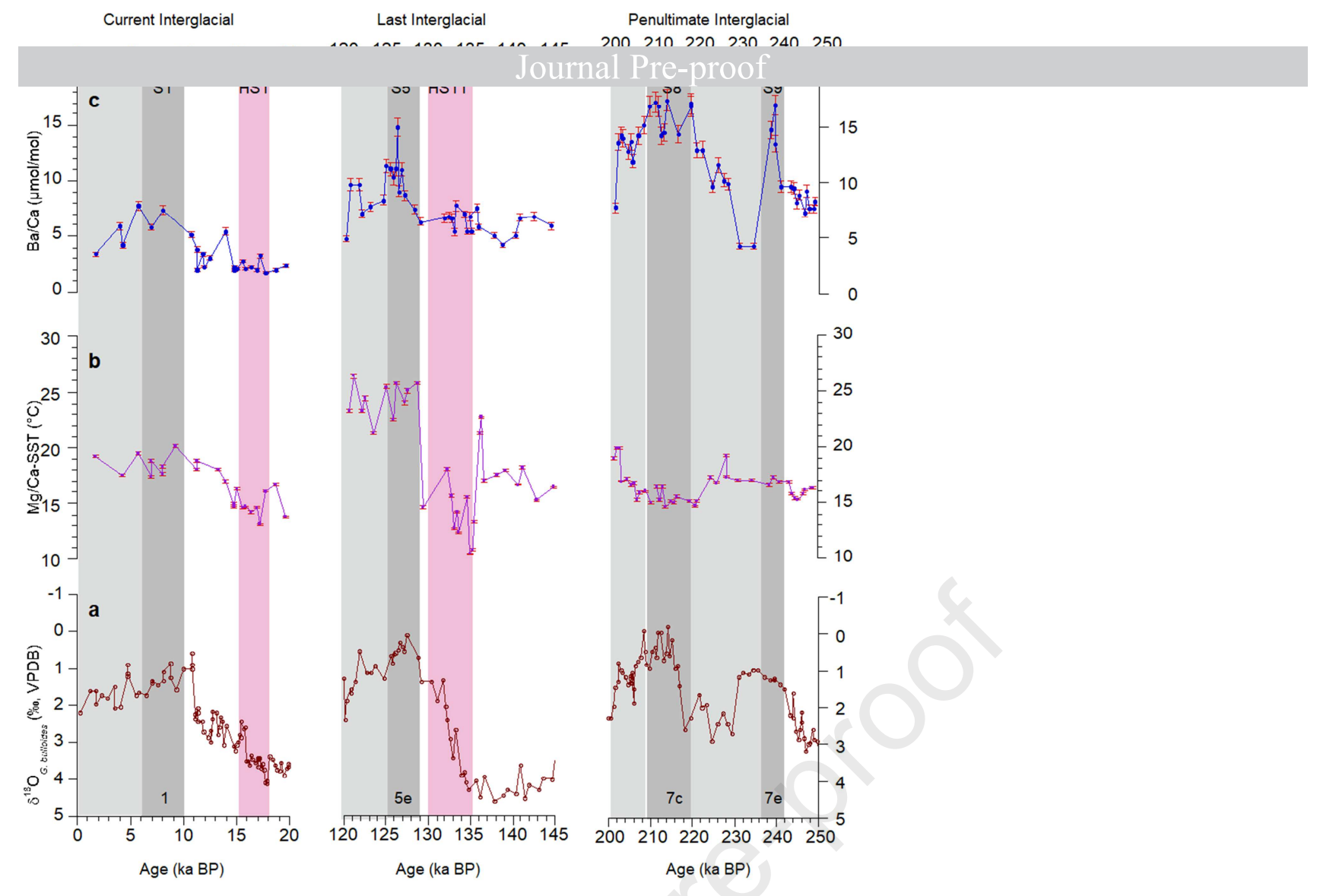

910 Figure 2: GDEC-4-2 results for the last three interglacials. (a) $\delta^{18} \mathrm{O}$ G. bulloides; (b) $\mathrm{Mg} / \mathrm{Ca}$-based SSTs from G. bulloides (blue); (c) $\mathrm{Ba} / \mathrm{Ca}$ in foraminifera as a proxy of river discharge. Vertical light grey bars indicate interglacial conditions $s . l$. and dark grey bars denote interglacials warm intervals and the interglacial s.s. Sapropel deposition intervals, Heinrich stadials (pink bar) is also shown. 


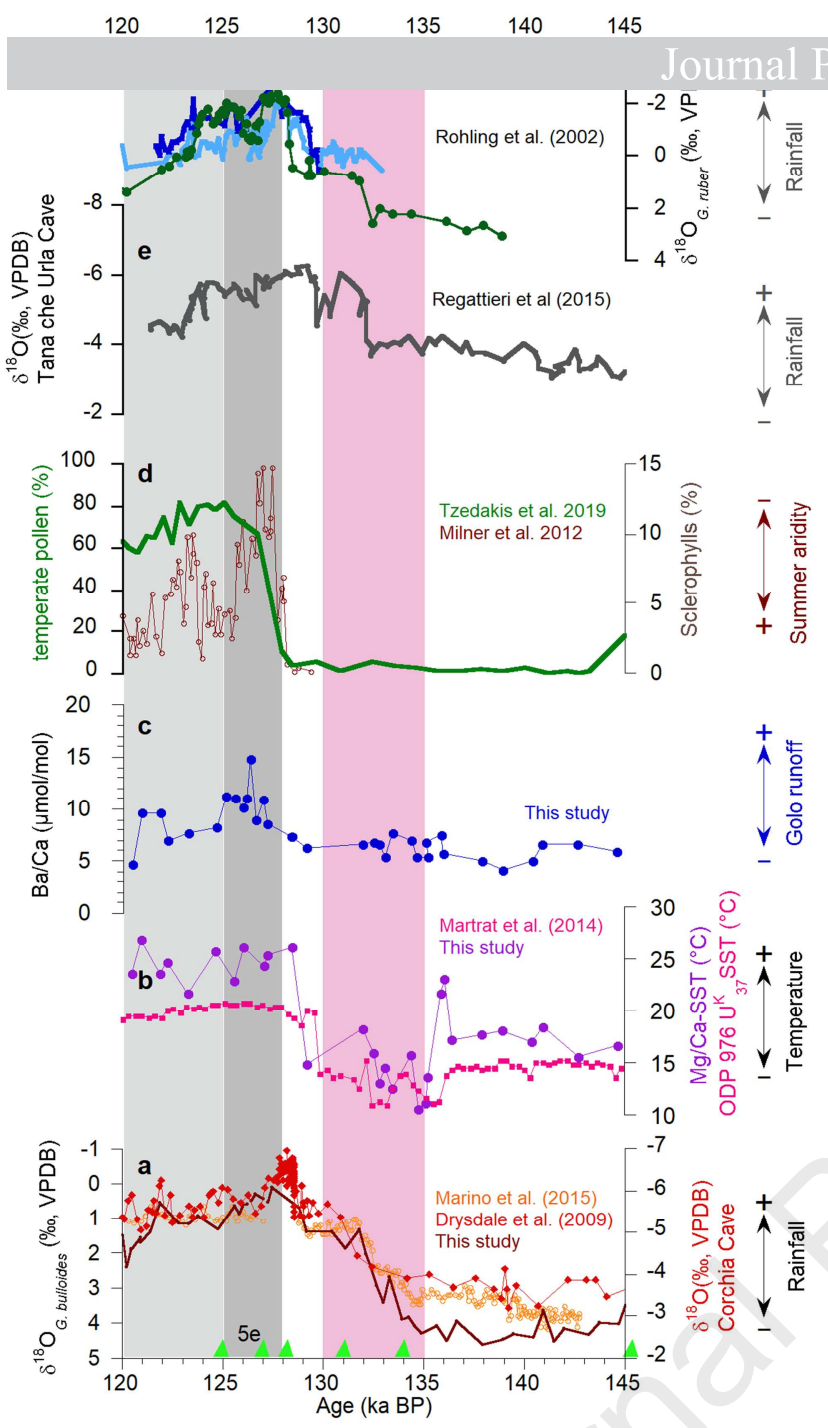

915 Figure 3: Comparison of GDEC-4-2 results, based on Marino et al., (2015) chronology, with regional records for MIS 5e. (a) $\delta^{18} \mathrm{O}$ G. bulloides of GDEC-4-2 (brown), ODP 975 (orange) (Marino et al., 2015) and $\delta^{18} \mathrm{O}$ of Corchia Cave speleothem (red open circles) (Drysdale et al., 2005) (b) Mg/Ca-based SSTs from G. bulloides (purple) from GDEC-4-2 and Uk37- SSTs from ODP 976 (pink) (Martrat et al., 2014); (c) Ba/Ca in foraminifera as a proxy of river discharge in GDEC-4-2; (d) Pollen data: temperate pollen (green) and Sclerophyllous from NE Greece (brown)(Milner et al., 2012; Tzedakis, 2019); (e) $\delta^{18} \mathrm{O}$ of

920 Tana urla Cave, Italy (Regattieri et al., 2014); (f) $\delta^{18} \mathrm{O}$ of $G$. ruber from sapropel cores in eastern Mediterranean (Rohling et al., 2002). Vertical light grey bars indicate interglacial conditions s.l. and dark grey bars denote interglacials warm intervals and the interglacial s.s. Timing of sapropel S5 shown by dark grey band is based on core site LC21 findings by Zeigler et al., 2010. Heinrich stadials (pink bar). Pink bar denotes Heinrich stadial HS11, based on Marino et al., (2015) chronology. Also shown at the bottom are tie points (black triangles) to synchronize GDEC-4-2 with the most up-to-date chronology of ODP 925975. 


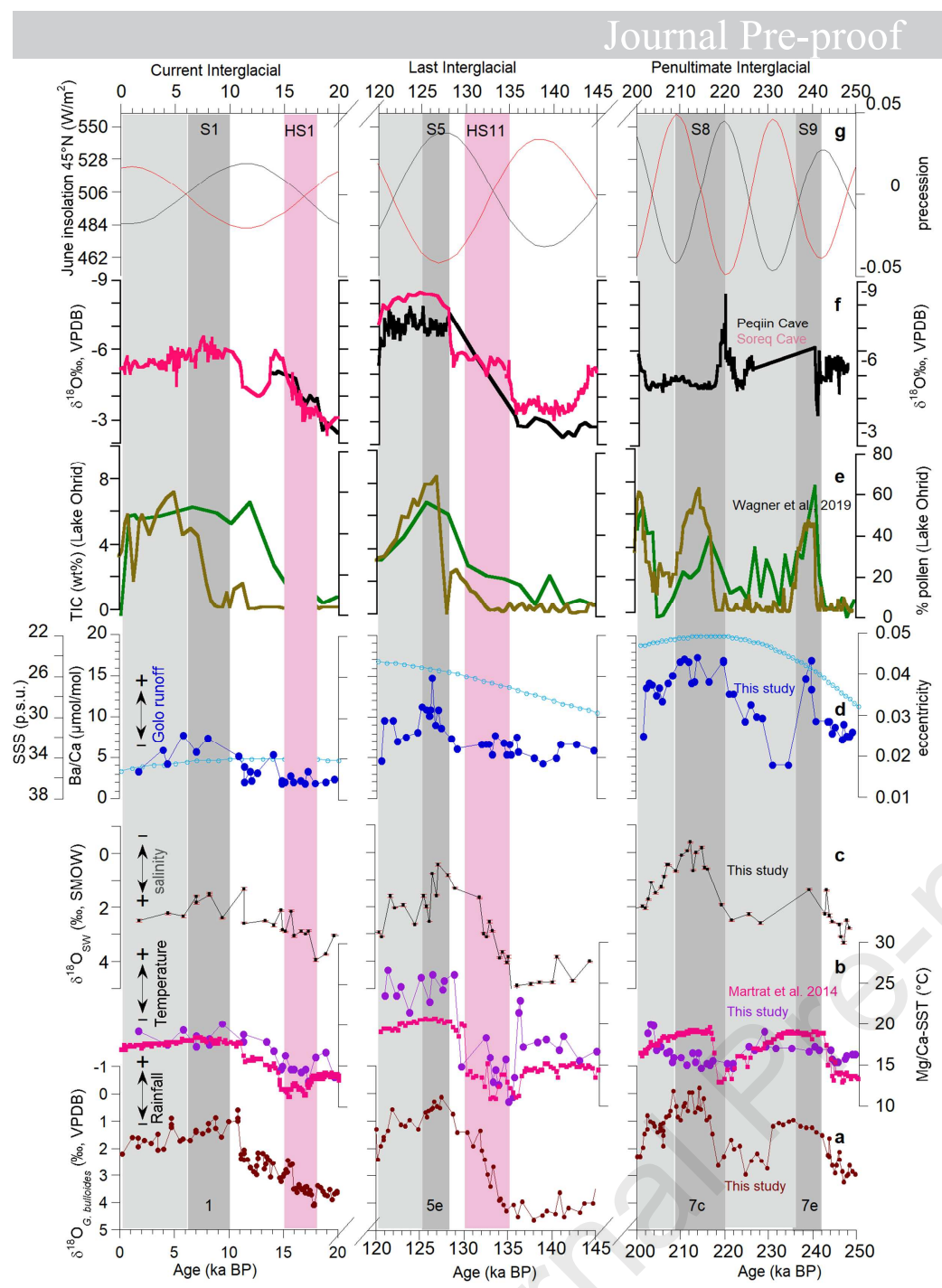

Figure 4. Comparison of records for current interglacial (Holocene) and last interglacial and penultimate interglacial from core GDEC-4-2 to other datasets. (a) $\delta^{18} \mathrm{O}$ G. bulloides (brown); (b) Mg/Ca-SST (this work; purple) and Uk37-SST (ODP 930 976; pink) (Martrat et al., 2014); (c) $\delta^{18} \mathrm{Osw}$ (grey), uncorrected for ice-volume changes (this work); (d) G. bulloides $\mathrm{Ba} / \mathrm{Ca}$ (analytical precession of $\pm 5.4 \%$ ) (this work; blue) and $\mathrm{Ba} / \mathrm{Ca}$-based SSS estimates and eccentricity (light blue dashed line); (e) Percentage of pollen from deciduous oaks at Lake Ohrid (green) and Lake Ohrid total inorganic carbon (TIC) concentrations (brown) (Wagner et al., 2019); (f) $\delta^{18} \mathrm{O}$ of Soreq (pink) and Peqiin (black) Cave speleothems; (g) Precession and June insolation at $45^{\circ} \mathrm{N}$. Vertical light grey bars indicate interglacial conditions s.l. and dark grey bars denote

935 interglacials warm intervals and the interglacial s.s. Sapropel deposition intervals (Ziegler et al., 2010), Heinrich stadials (pink bar) are shown on top. 


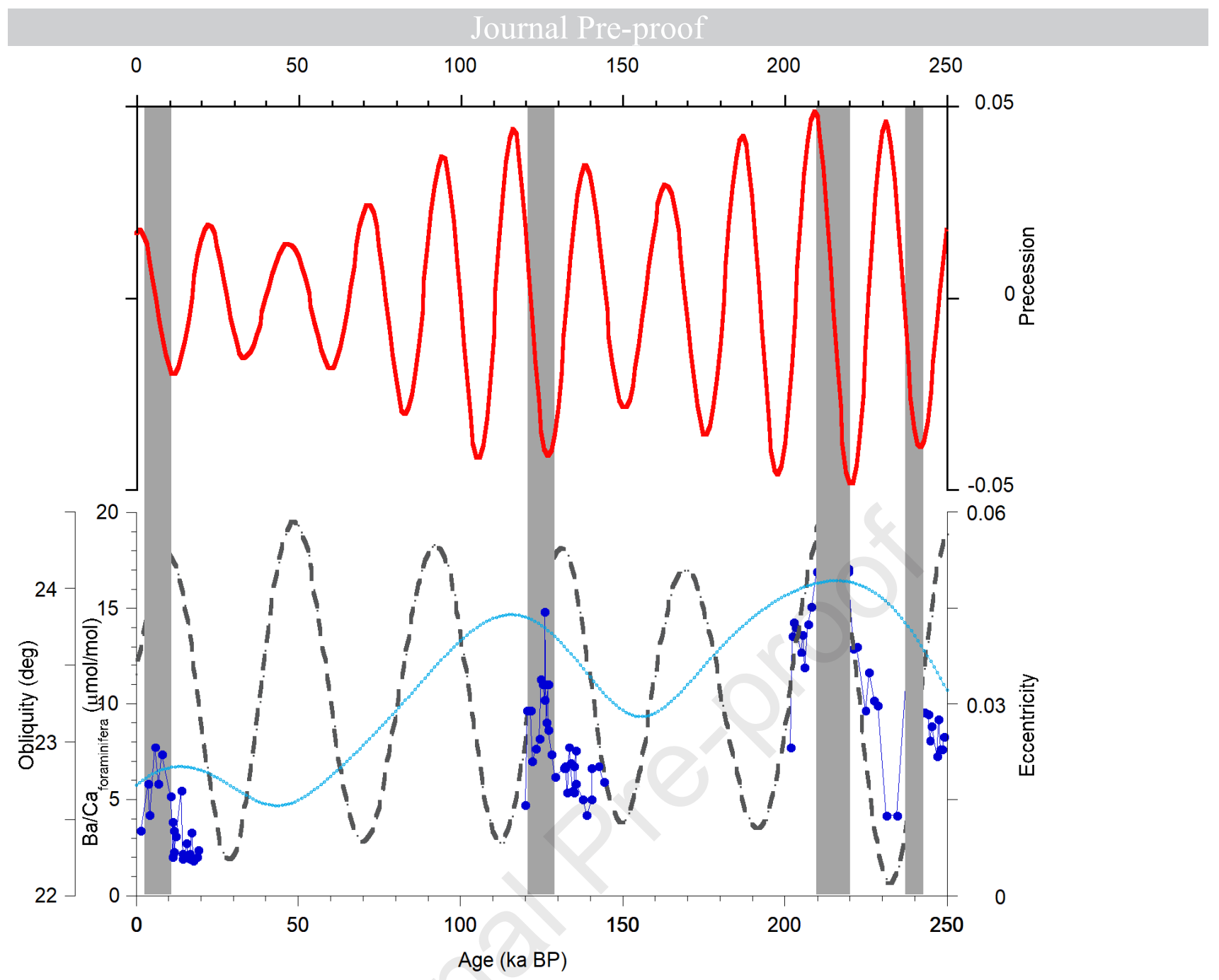

Figure 5. Comparison of $\mathrm{Ba} / \mathrm{Ca}$ (runoff/rainfall) record (deep blue) with orbital forcing; Obliquity (grey dashed curve), eccentricity (light blue) and precession (red). Grey bands indicate warm periods MIS 7, 5 and MIS 1. Changes in the amplitude of $\mathrm{Ba} / \mathrm{Ca}$ follows the eccentricity cycle, with higher $\mathrm{Ba} / \mathrm{Ca}$ during MIS-7, relatively lower $\mathrm{Ba} / \mathrm{Ca}$ in MIS-5, and the lowest $\mathrm{Ba} / \mathrm{Ca}$ in MIS-1, corresponding to the respective insolation maxima of the 100 ka-eccentricity cycle during each interglacial. This trend in the change in magnitude of river discharge due to winter rainfall confirms the idea of eccentricity modulation of the precession-driven rainfall/runoff in the Mediterranean during the late Pleistocene. 


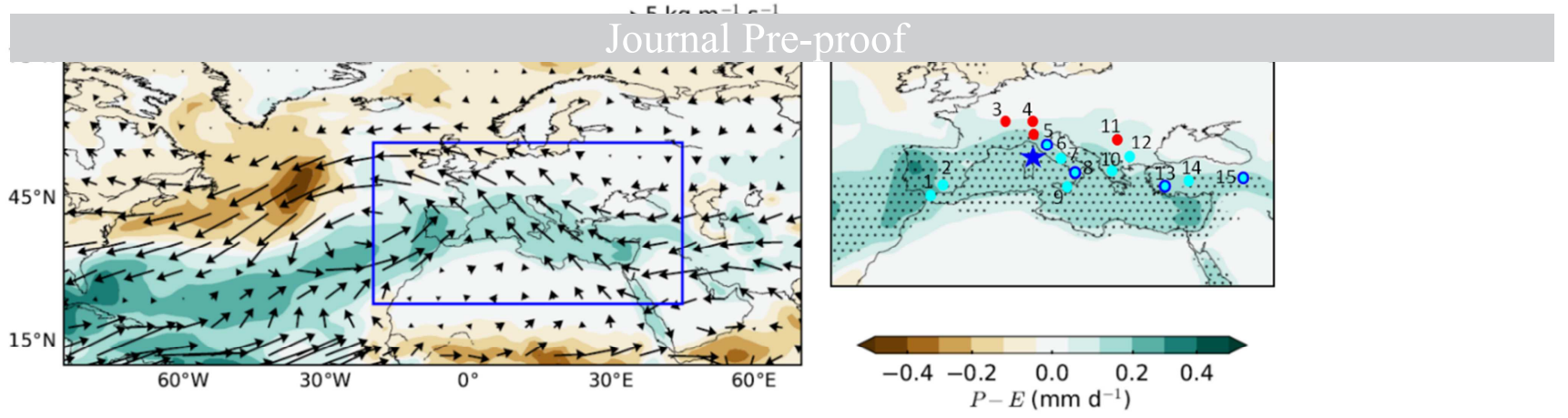
model ensemble for 11 PMIP3 models, Table S3) is shown using coloured contours. A band of higher Holocene moisture 950 convergence runs from the southwestern North Atlantic to the Iberian Peninsula, and across the Mediterranean, accompanied by a decrease in the north and northwestern North Atlantic. The corresponding differences in mean moisture transport for the region (arrows) indicate increased southwesterly transport into the western Mediterranean, as well as decreased westerly transport (shown by easterly arrows) across the eastern Mediterranean as well as the northern North Atlantic. b) Zoomed map of the boxed region in (a), showing the same P-E difference in the Mediterranean, with stippling showing where at least

9559 of the 11 models agree on the sign of the change. Coloured circles denote sites with data constraining hydroclimate changes (this work- blue star, high rainfall/ high lake levels- blue circles, dark blue lined for past three interglacials) that are consistent with high winter precipitation during the early-middle Holocene. Red circles denote the lakes with lower lake levels during the Holocene. 


\section{Declaration of interests}

$\bigotimes$ The authors declare that they have no known competing financial interests or personal relationships that could have appeared to influence the work reported in this paper.

$\square$ The authors declare the following financial interests/personal relationships which may be considered as potential competing interests: 